\title{
TECHNICAL AND ECONOMIC FEASIBILITY OF SOLAR IRRIGATION PUMPING SYSTEM: A REVIEW
}

\author{
Sarr Aminata ${ }^{1,2}$, Diop Lamine ${ }^{1, *}$, Diatta Ibrahima ${ }^{3}$, Wane Y. Deffa ${ }^{1}$, Diallo D. Mariama ${ }^{1}$, Ansoumana \\ Bodian $^{4}$, Seck M. Sidy ${ }^{3}$, Mateos Luciano ${ }^{5}$ and Lamaddalena Nicola ${ }^{2}$ \\ ${ }^{1}$ Faculty of Agronomic Sciences, Aquaculture and Food Technology (S2ATA), Gaston Berger University, Saint-Louis, \\ Senegal. \\ ${ }^{2}$ Irrigated agriculture, Mediterranean Agronomic Institute of Bari (CIHEAM-BARI), Bari, Italy. \\ ${ }^{3}$ Interdisciplinary Research Group in Support of Regional Planning and Local Development, Gaston Berger University, \\ Saint-Louis, Senegal. \\ ${ }^{4}$ Faculty of Arts and Humanities UFR, Gaston Berger University, Saint-Louis, Senegal. \\ ${ }^{5}$ Spanish National Research Council. \\ *Corresponding: Diop Lamine: lamine.diop@ugb.edu.sn
}

\begin{abstract}
Climate change has become a major constraint to the development of rain-fed agriculture due to the decline of rainfall. Therefore, irrigated agriculture is an alternative allowing farmers to have more access to water in order to meet crop water requirements. However, irrigated agriculture faces a major constraint related to the accessibility of energy sources used in pumping water. In general, the most common energy sources used in pumping water for irrigation are fuel and electricity. Nevertheless, they are very expensive, are not always accessible particularly in rural areas in Africa and have a negative impact on the environment; hence the need to find alternatives to solve this problem. This review focuses on the technical and economic feasibility of solar irrigation pumps and the impact of their use on the environment. Several aspects related to solar pumping have been discussed, namely the components of the solar pumping system, the energy source used, the principle of operation of the system, the technical, economic, and environmental feasibility. Reviews show that the use of solar irrigation pumps is a technically and economically feasible alternative in several areas with less environmental impact.
\end{abstract}

Keywords: Solar pump; Irrigation; Energy.

\section{Introduction}

The world is currently subject to a very important rapid population growth [1]. In 1960, the world's population was estimated at three billion people. This population is expected to range from 8.5 to 8.6 billion, 9.4 to 10.1 billion, and 9.4 to 12.7 billion in 2030, 2050, and 2100, respectively [2]. In addition, Africa is one of the world's regions with the highest population number. It occupies second largest population behind Asia [3]. While several challenges including the high growth in food requirements are resulting from rapid population growth [4]. According to [5], population growth is one of the major factors driving the need to effectively increase and improve food supply. Therefore, agriculture is considered as the key sector to achieve food security, sustainable development, and to reduce poverty. Moreover, world production is expected to rise by $60 \%$ between 2005 and 2050 [6]. This increase is necessary to satisfy the world population demand in 2050 [7]. The rise in agricultural productivity leads to an increase in farmer's income and decrease of poverty [8]. In fact, agriculture is the major source of income for $90 \%$ of the rural population in Africa [9]. An increase of $1 \%$ in crop productivity reduces the number of poor people by $0.72 \%$ in this continent [9]. Also, agriculture accounts for a large part of Africa's world trade [10] and employs $70 \%$ of the population as smallholder farmers [11].

However, several factors jeopardize the development of agriculture [11]. These constraints are generally related to water scarcity, climate change, land degradation, and pests [12]. Agriculture is predicted to be affected by the effects of climate change, particularly for smallholders with a low ability of adaptation [13]. Climate change is expected to affect water resources in different ways, including changes in the amount and pattern of precipitation and droughts. These changes in precipitation can highly affect agricultural production in all regions of the world. Changes in precipitation patterns are also likely to reduce surface water quantity and groundwater recharge rates [14].

For this purpose, irrigation can be seen as an alternative. It could improve land productivity, enhance the resilience of farms, stabilize and increase farmers' incomes, reinforce food security and nutritional diversity, 
and create jobs [15]. In fact, the development of irrigation faces many constraints. Among them, the cost of energy is one of the most recurrent and important. The cost of energy is very high, especially for smallholder farmers who are using pumps in irrigation. According to Sands et al. [16], large amounts of energy are consumed during agricultural production, in which the highest part is used in irrigation [17]. As a result, energy costs have a particular impact on agricultural production costs. The energy sources used to power pumps are mainly diesel and grid. However, the cost related to these energy sources is very high and is not always accessible to farmers, and they negatively impact the environment. These conventional energies are non-renewable and are combined with climate change risks due to $\mathrm{CO}_{2}$ emissions [17]. Indeed, the world's population demand for energy is increasing due to the high population growth. As a result, the use of energy from fossil fuels is increasing, leading to a scarcity of fossil fuel resources, increased pollution caused by greenhouse gas generation, and permanent variations in fuel prices [18]. Moreover, according to Calvet and Marical [19], an increase of more than $30 \%$ in fuel prices has occurred between 1990 and 2006. In addition, regarding electricity accessibility, 1.4 billion of the world's population do not have electricity, and $85 \%$ of them reside in rural areas [18]. Energy supply is considered for this reason as an inhibiting factor in the development of irrigation. Consequently, alternative energy sources such as solar energy have to be explored to help farmers to sustainably extract water from the source. Solar pumping is a technique in which radiation is converted by solar panels to produce hydraulic energy. This system is a way for energy cost and pollution reduction [20], hence the importance of further study on solar pump use in irrigation. In addition, according to [21], the investment cost and the levelized cost of electricity with regard to the use of solar energy is dropping over the years as shown in Figure 1. This decrease in price confirms that solar energy may be considered as alternative to the use of traditional energy.

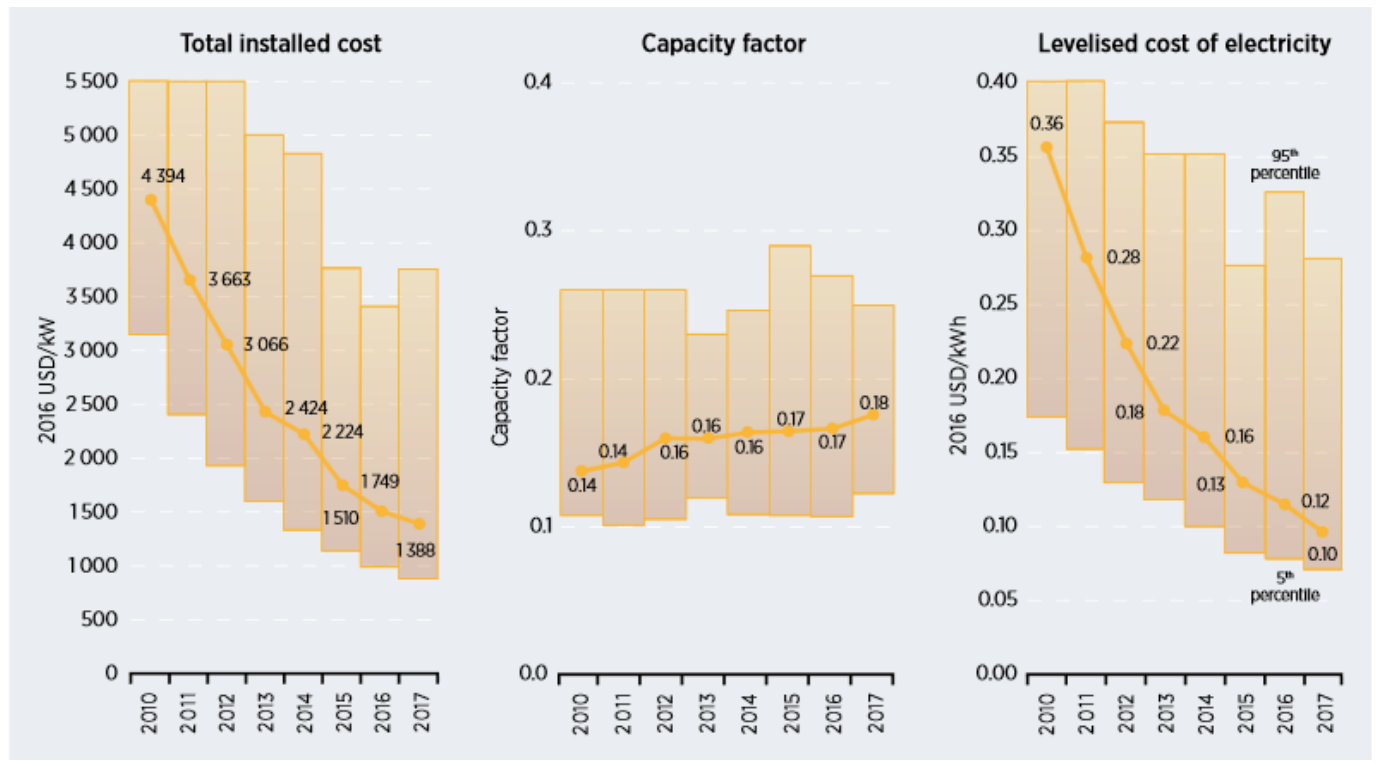

Figure 1: Decrease in installation cost and in levelized cost of electricity regarding solar energy used between 2010 and 2017 [21].

The objective of this study is to acquire more knowledge on the use of solar irrigation pumps in irrigation. This study provides information on the components of a solar pumping system, the operating principle, the technico-economic feasibility, as well as the impact of the use of these pumps on the environment.

Several authors performed reviews on the solar pumping system: [22], [23], [24], [25], [26]. Some of those studies are specific to a given area, others are more focused on the designing of solar irrigation pumps. This study is a complement to those first ones. It is not specific to a given area and gives an idea on the technical and economic feasibility as well as on the impact of the use of solar pumps on the environment. The very recent literature used, which dates from 2003 to 2020, gives an idea of the actual situation of the use of solar irrigation pumps in the world.

This review is based on 131papers with various sources: journal articles, review articles, reports, theses, conference reports and websites. They are published at different levels namely Renewable Energy, Renewable and Sustainable Energy Review, International Journal of Agricultural Engineering, Spanish Journal of Agricultural Research, International Journal of Computer Applications International Journal of Current Microbiology and Applied Sciences, International Journal of Innovative Research in Science, Engineering and Technology, International Journal of Civil and Structural Engineering Research, International Journal of Engineering Research and Technology, among others. 


\section{Generality on source of energy for irrigation pumps}

Irrigated agriculture provides $40 \%$ of world food production [27]. It is expected that access to irrigation will increase opportunities for farmers' production [28]. Groundwater will remain the principal freshwater source for irrigation for large areas of agricultural production beyond the depletion of surface water sources [29]. The world's irrigated area is estimated at 301 million hectares, of which $38 \%$ is irrigated from groundwater [30]. In addition, one-fifth of food provided worldwide comes from groundwater-irrigated agriculture [31] making necessary the need to find ways to extract groundwater. Pumping is mainly used for groundwater extraction. According to Scherer [32], pump is the fundamental element of most irrigation systems. However, energy requirements for pumping water for irrigation are considerable [33]. Therefore, the management of energy used for irrigation is an important element in the development of agriculture. On a worldwide scale, about $7 \%$ of total world energy consumption is used for water supply [34]. Also, the high energy consumption of water in South Asia is significantly related to irrigated agriculture [34]. Different sources of energy (human energy, animal energy, wind energy, solar energy, fuels energy like diesel in the case of smaller generators, and hydropower) are always used by people in the process of extracting water [23]. Hand pumps, submersible electric pump equipped with diesel fuel generator, diesel direct drive drilling engine, and submersible solar pumps are highly common types of engines used in remote communities [24]. In fact, the choice between the different energy sources depends on economic and technical aspects in relation to the water source used, the environment where pump is used and other instructional and social parameters [35]. Nevertheless, the main energy sources used in the world today are oil, coal, gas, hydropower, nuclear, wind, and solar. However, despite the profitably of using renewables energy such as solar from the economic and environmental point of view, the use of these energy sources is far below compared to those of oil, coal, and gas. Thus, from 2010, solar energy utilization began to increase. However, it is still far behind of the use of oil, coal, and gas as shown in Figure 2.

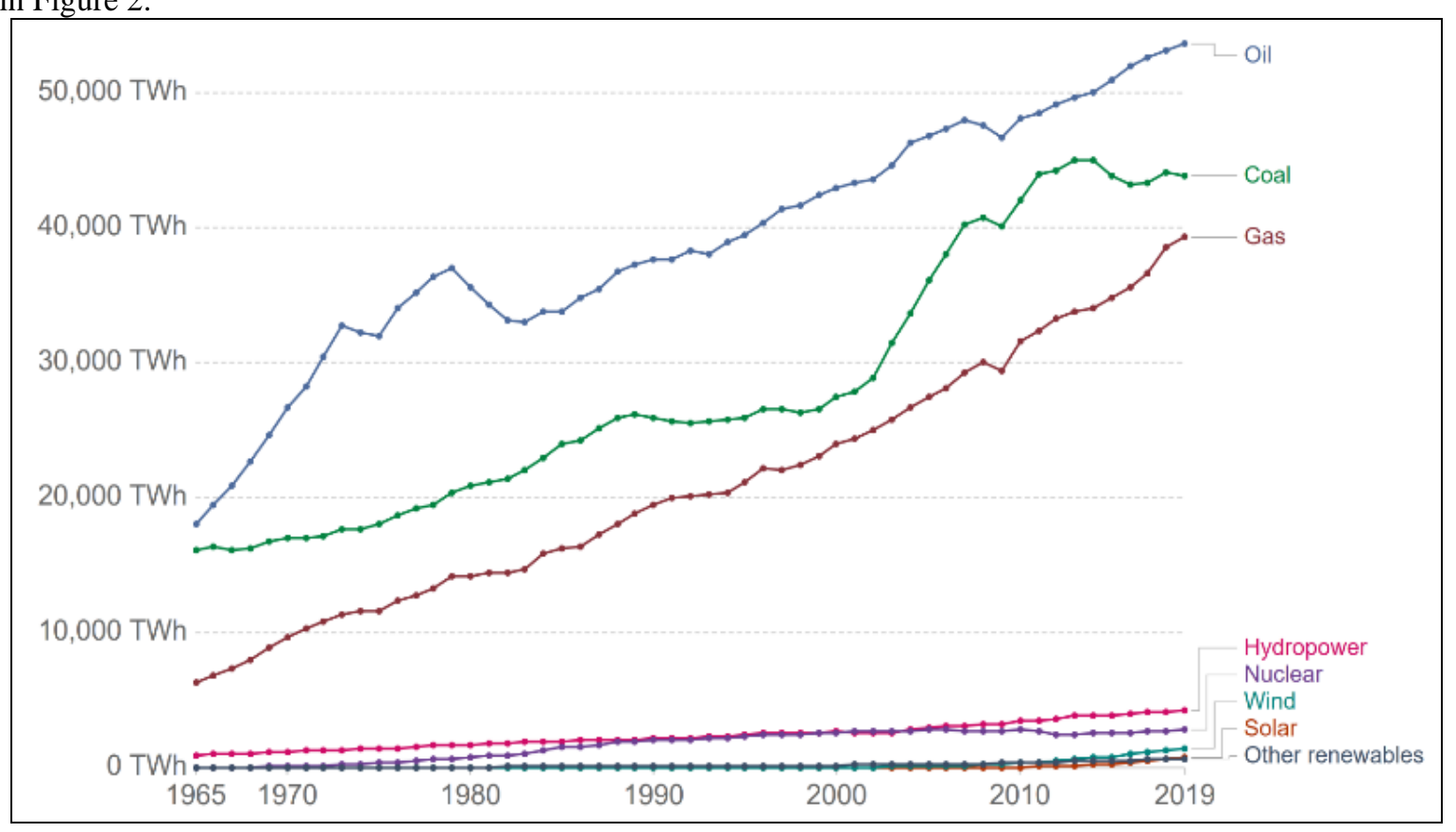

Figure 2: Main energy sources used in the world [36].

According to USDA [37], electric motors and internal combustion engines are the most common types of engines used in most irrigation pumping systems. However, fuel cost is increasing [38]. Also, Linn and Ya [39] estimated that more than $70 \%$ of Myanmar's rural population for example, still has difficulty accessing electricity. In fact, the high electricity and diesel prices and frequently deficit of reliable energy supply have an impact on the pumping needs for small and large farmers' irrigation. Electricity is not available or is only occasionally available in many rural areas [40]. Thus, Linn and Ya [39] concluded that solar and wind energy are the most appropriate sources of energy in rural areas. Indeed, the more intensive use of renewable energies, namely wind and solar energy, and the reduction in diesel fuel consumption will positively affect the development of the use of clean energy. They have also the possibility to reduce polluting emissions into the environment and will improve the living standards of people in rural areas. Given these challenges, they attested that wind and solar potential should be used to provide electricity to rural residents. In addition, according to SELF [38], rural areas are at the end of the fuel supply chain due to their poverty, which often means that they 
are not able to obtain fuel in the first place. Consequently, the use of energy from the sun for pumping system is a potentially viable alternative to the use of conventional (diesel and electricity) [40].

Therefore, solar energy is increasingly used. In fact, photovoltaic (PV) solar generators are an interesting alternative to reduce the cost of electricity consumption because they can be sized on-site, allow autonomous operation and have a low environmental footprint. In addition, they are economically competitive since photovoltaic panel prices started to fall in 2010 and have been reduced to less than half in just 5 years [32]. In addition, pumps and controllers' prices decrease. However, this drop in prices is lower compared to panels and is estimated at 30\% between 2009 and 2017 [40]. Moreover, according to GIZ [42], Solar panel is subject to an important decrease from 2007 to 2017, based on solar PV price index as shown in Figure 3, which reflect the high decrease in panels' price.

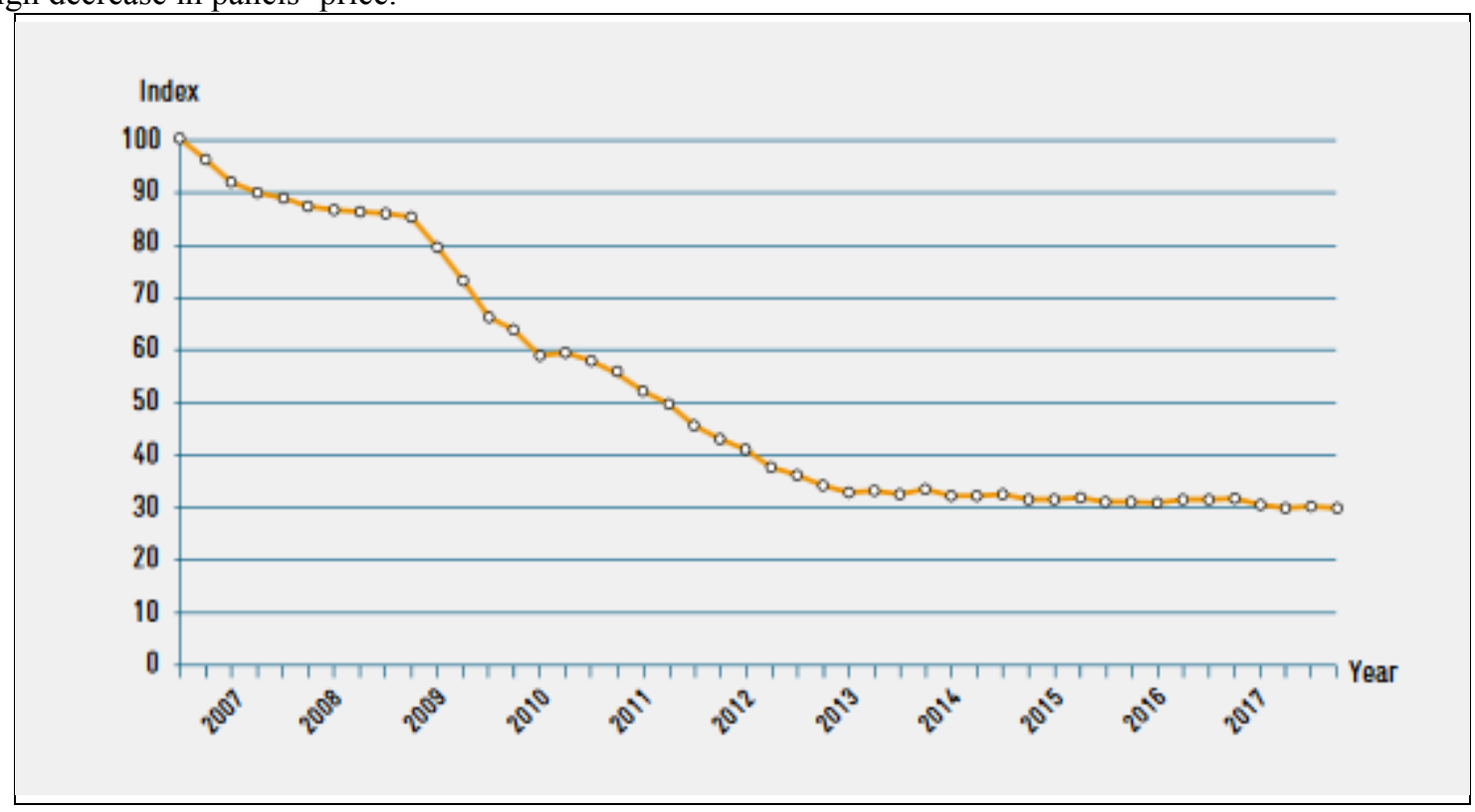

Figure 3: Solar PV price index for installed roof-mounted systems of up to 10-kilowatt peak without tax [41].

\subsection{Use of solar irrigation pump}

The use photovoltaic solar cells for pumping irrigation water in 1977 in Nebraska was among the earliest experimental uses of PV solar cells. Within the last decennium, the use of solar irrigation pumps has expanded in both China and India [42]. More lately, it is observed an increase in the use of solar pumps in Africa [42].

Solar irrigation solutions are attracting increasing interest worldwide, as evidenced by the increasing demand from agricultural institutions in developing countries for installation, financing, and training [39]. Solar systems are one of the sustainable alternatives to conventional systems, receiving significant consideration [43]. Sustainable solar energy by using solar cells (PV) when pumping water for irrigation is a recent and successful technic. Photovoltaic systems are being used to provide energy in many developing countries, especially in isolated regions [44]. The increase in the use of solar pumps in India shown in Figure 4 is an illustrative example.

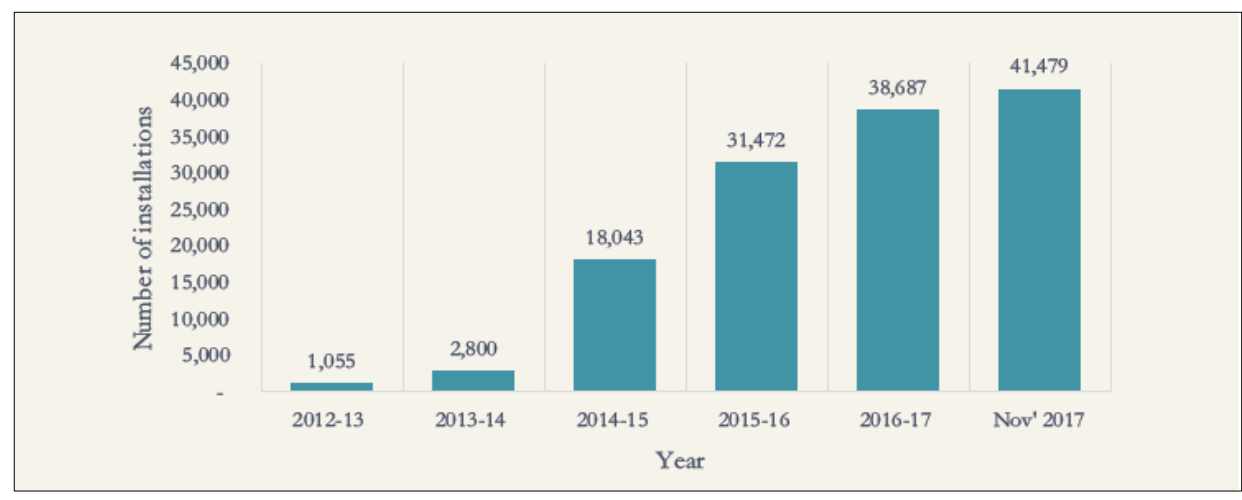

Figure 4: Evolution of the use of solar pump in India [45]. 


\subsection{Solar irrigation pumping system components}

A solar powered system for irrigation pumping is composed of generator (set of panels), electronic components (inverters and pump controllers), pump, support structure, cables, and pipes [23], [46], [47], as shown in Figure 5 .
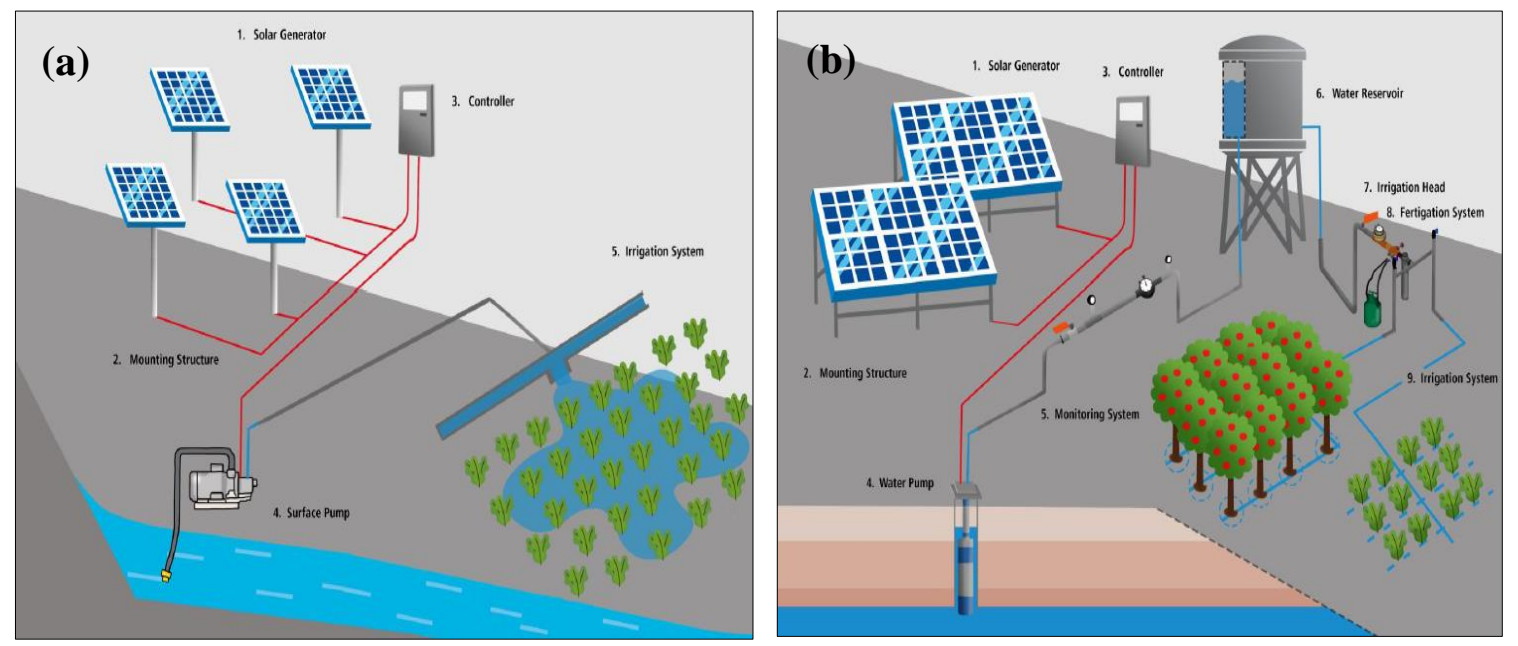

Figure 5: Main components of solar irrigation pump [48]. a) Solar irrigation system without reservoir and b)

Solar irrigation system with reservoir.

\subsubsection{Photovoltaic generator}

A photovoltaic generator is a set of interconnected photovoltaic panels [48]. It is made up of a set of PV (Photovoltaic) solar array interconnected in parallel or/and in series to provide the direct current (DC) as well as the voltage desired [49]. The photovoltaic solar generator is a "non-linear" electrical energy source that provides a variable voltage and current value depending on lighting and temperature conditions [49]. It is an electricity generator that absorbs sunlight and transforms it into usable electricity. More than $80 \%$ are constituted of solar crystalline silicon cells which can be classified as monocrystalline or polycrystalline silicon, amorphous, or hybrid as shown in Figure 6. The efficiency of solar cells differs depending on the type of crystals they contain. This efficiency is estimated at $17 \%$ for monocrystalline crystals, $15 \%$ for polycrystalline crystals, and $7 \%$ for amorphous crystals [50].

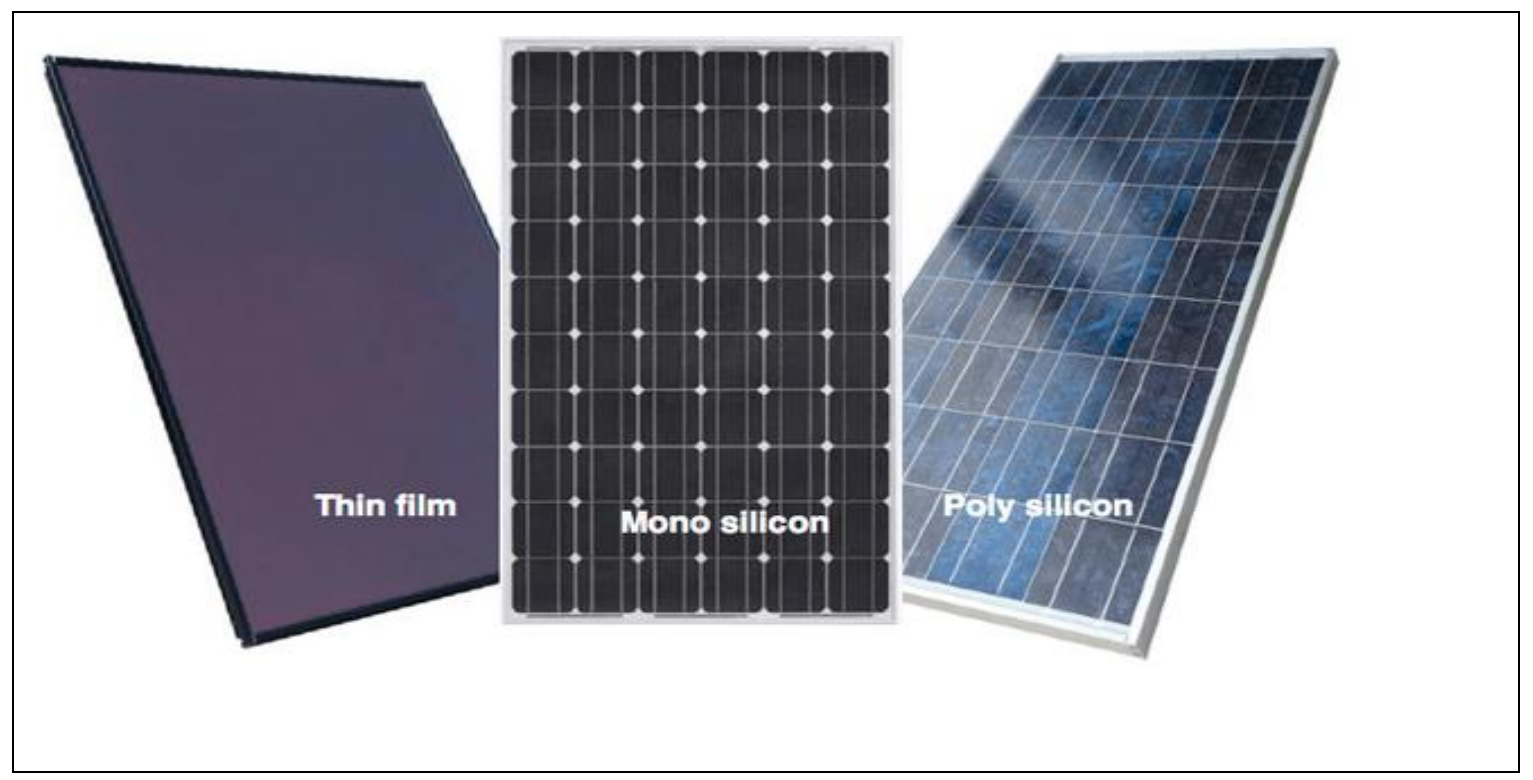

Figure 6: Solar modules types [51]. 
In addition, panels are in series configuration to ensure the appropriate operational voltage of the selected inverter: it is "a string or a branch". However, to obtain the necessary current (power), the modules are connected in parallel [49].

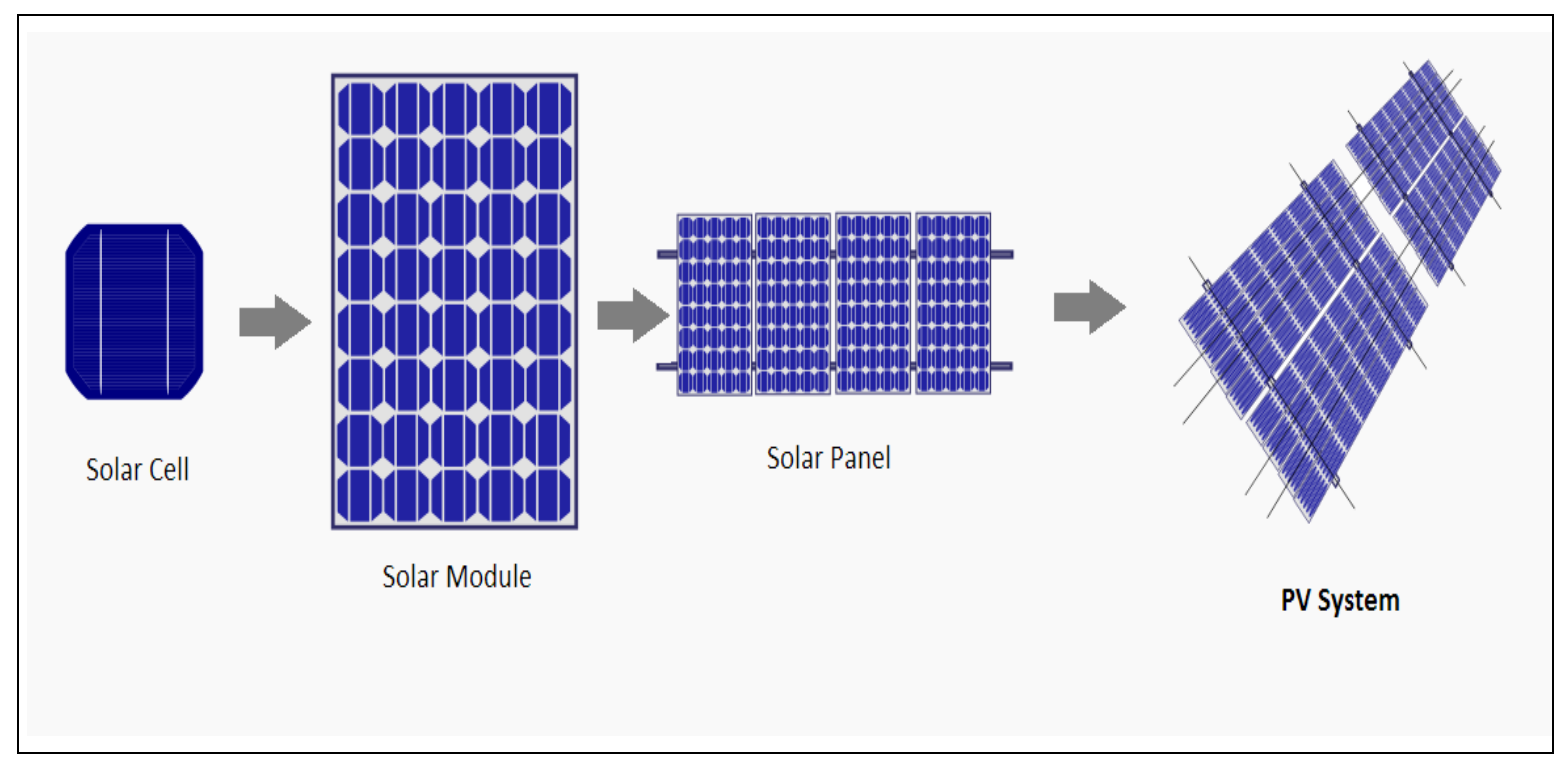

Figure 7: Photovoltaic generator [52].

\subsubsection{Solar pump inverters and controllers}

The controller and inverter are combined in one device and together represent the link between the pump and the PV generator as shown in Figure 8.

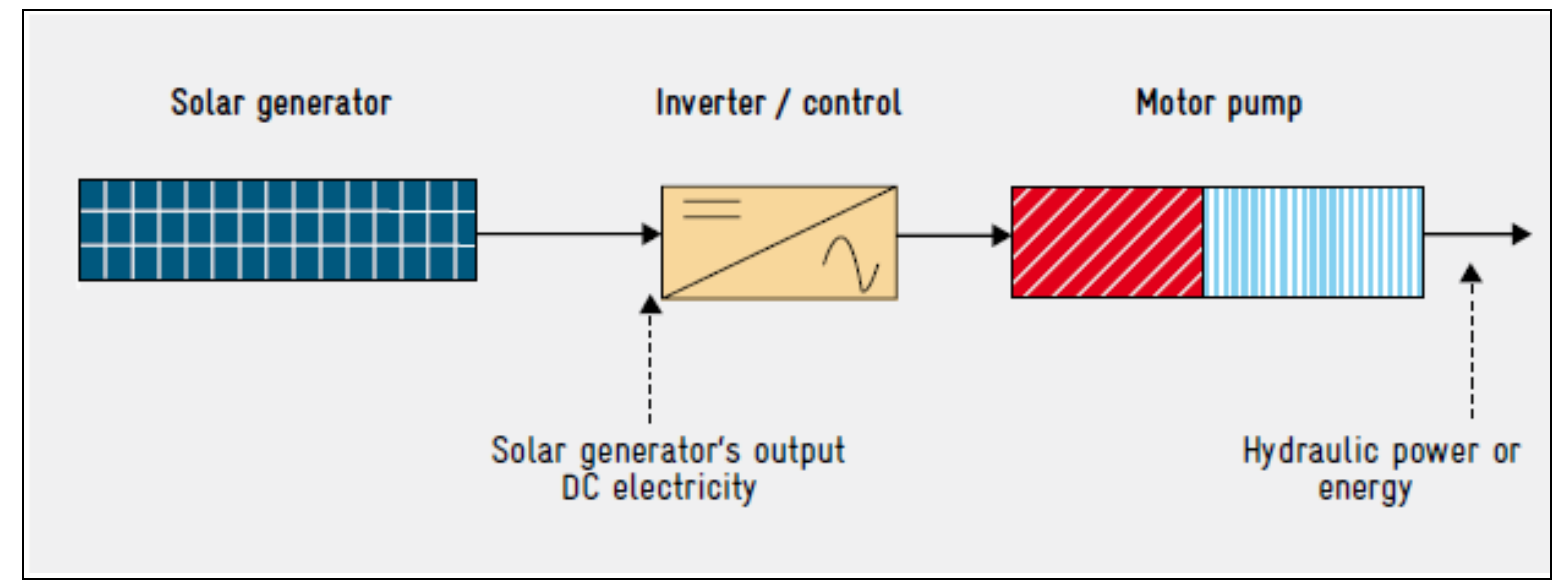

Figure 8: Controller and Inverter [41].

An inverter is an electronic power device. In general, a direct current (DC) is supplied by the solar panels while the pump can be of the DC or AC type. Thus, direct current of the solar panels must be converted from direct current to alternating current for an AC (Alternative current) pump [53]. This transformation is carried out using an inverter. In fact, the inverter is used in the process of conversion of DC current into low or high DC current or to convert DC current into AC current which result in two types of inverters: DC-DC converter and DC-AC inverter [54]. Inverters for solar photovoltaic systems are often subjected to extreme conditions, due to their operation during many hours of sunlight, combined with the use of temperatures above $40^{\circ} \mathrm{C}$. The life of the inverter is estimated at more than 20 years with appropriate design [54]. In addition, it is in charge of controlling engine speed and maximum power point tacking (MPPT) [55].

The pump also needs a controller that can adapt the power directed to the pump with the power supplied by the energy source. Generally, the controller is equipped with a voltage protection capability. This protection capacity allows the pump to be switched off if the supply voltage is insufficient or very high [56]. The controller 
protects panels against polarity reversal and switches off pump during overload. It also protects the pump by turning off the pump in case of lack of water in the well and allows the pump to operate 20 minutes after raising of the water level [56].

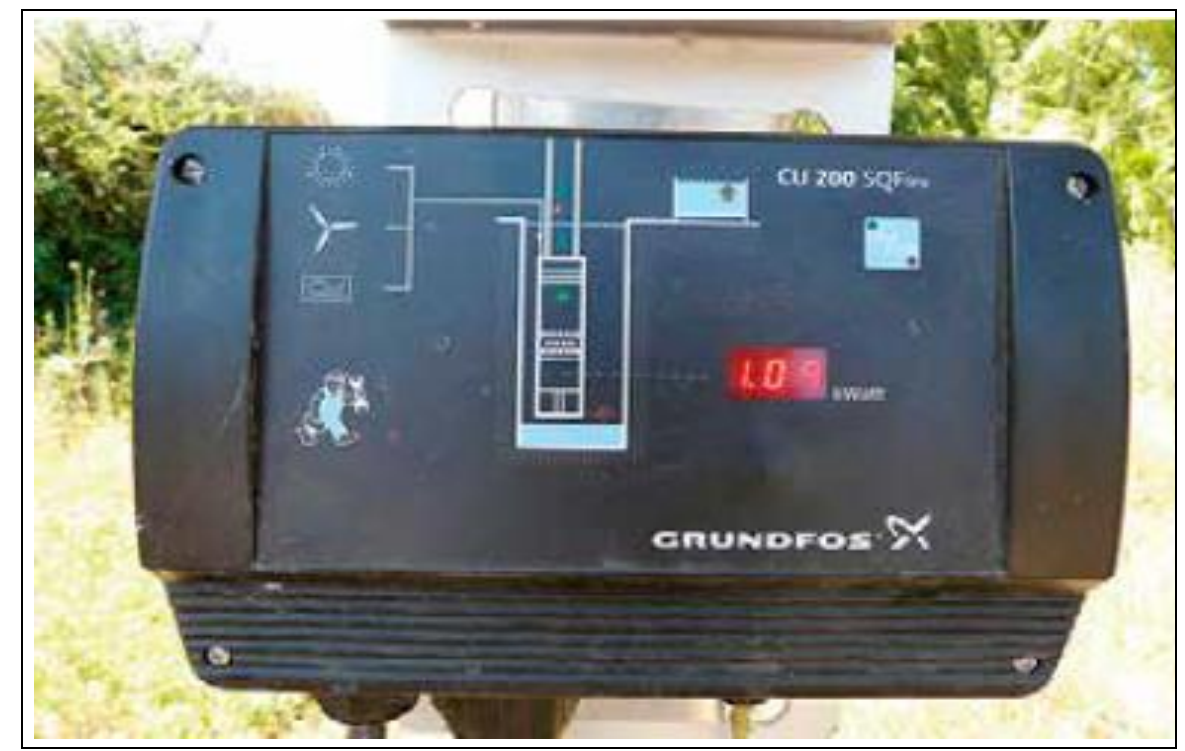

Figure 9: Solar pump controller and inverter [41].

\subsubsection{Solar pumps}

There are direct connections from the pumps to the solar network. This connection is made by the continuous current generated by solar panels. Various PV pump capacities are provided depending on the water demands $[23,46,47]$. Submersible pump is mainly used in area where water is extracted from groundwater. For example, $89 \%$ of groundwater used in India is allocated to irrigation, hence promoting the development of using solar submersible pumping technology is becoming important [57]. Either surface water or deep well water can be abstracted using submersible pumps. Submersible pumps are higher in cost. However, they are more durable and are more accurate compared to surface pumps [58]. According to USDA [59], it is recommended to use submersible pumps when water is pumped from more than 3.7 or $4.6 \mathrm{~m}$ to avoid troubles with suction lift. Submersible pumps are classified into three main types: centrifugal pumps, helical rotor pumps, and diaphragm pumps.

Centrifugal pump is normally a surface pump and is suitable for use where the water level is $7 \mathrm{~m}$ above the ground [59]. In fact, the overall dynamic height in the pumping system consists of $14 \mathrm{~m}$ with a maximum estimated suction head of $7 \mathrm{~m}$. Thus, centrifugal pump is unable to operate if the groundwater table is below 7 $\mathrm{m}$ deep. However, an increase in the discharge head is possible below $7 \mathrm{~m}$ suction height, which allows water to be pumped also in deeper wells by implementing an internal pump known as "cut-down" [59]. However, they are often submerged [60]. Centrifugal pumps have high flow rates while providing a lower head (discharge pressure) in comparison to the other categories. These centrifugal pumps with variable frequency AC or DC engines were the first generations of solar pumps. They had a hydraulic efficiency ranging from 25 to $35 \%$ [61]. Centrifugal pumps use fast velocity rotation for water drawing across pump orifice. The centrifugal impeller is used by most AC pumps [62]. It can be used when pumping water from relatively short boreholes, lake, channels, open wells, tanks [59].

In addition, helical rotor pumps, on the other hand, are "positive displacement" pumps with higher pressures. The flow rate is lower than that of centrifugal pumps, but they can provide an adequate flow rate to meet most requirements. These pumps are characterized by their low photovoltaic power estimated on average at $250 \mathrm{Wp}$, and their water efficiency of that is able to reach $70 \%$, and their lower capital of investment [62]. In addition, the positive displacement pump is presently utilized in several solar pumping networks. Water is conveyed by this pump in a cavity and drive with a piston or a helical screw for the rising [63]. In addition, submersible diaphragm pumps are a positive displacement pump with the ability to pump up to about 20 Liter/minute from shallow wells of less than 30 meters deep and smaller volumes of water from wells depths up to about 70 meters [61]. Currently, centrifugal and positive displacement pumps have hydraulic efficiencies of more than $90 \%$ [62]. 


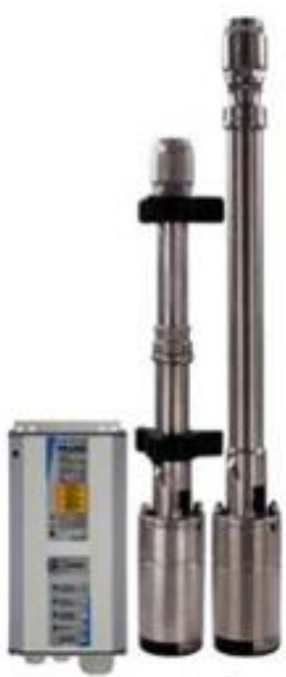

Submersible helical rotor

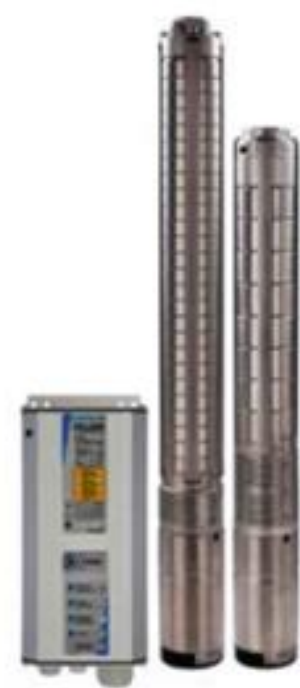

Submersible centrifugal

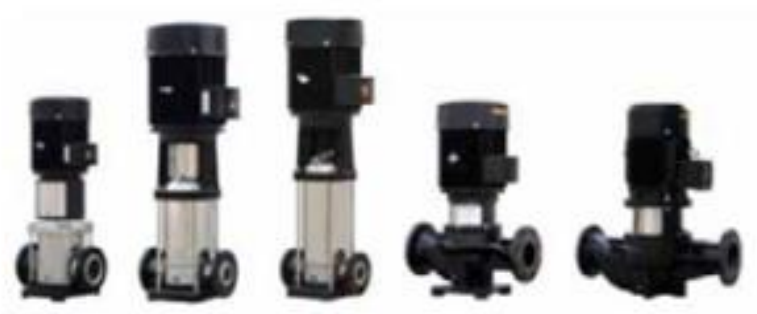

Surface centrifugal pump

Figure 10: Solar irrigation pump [63].

\subsubsection{Support structure and monitoring mechanism}

The stability and protection of the installed solar panels against theft and natural damage are provided by the support structure shown in Figure 11. A manually tracking system attached to the support structure is able to ensure maximum water flow. In fact, Tracking increases water flow as it enables modules facing sunlight when shifting across the sky $[23,46,47]$.

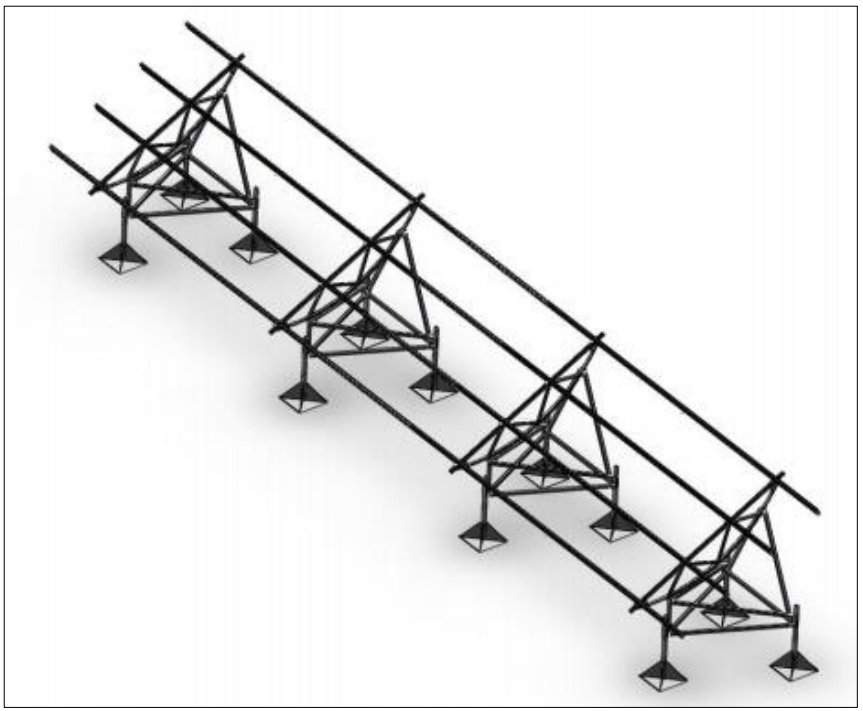

Figure 11: Solar support structure [64]. 


\subsubsection{Other components}

Other elements are essential for the installation of a solar pumping system. These are the foundations for holding support structures and pumps, the electrical interconnections, which consist of cables, junction boxes, connectors, and switches; the grounding kit that provides protection in the event of lighting or short circuits, as well as pipes and fittings for connection during installation [23,46, 47].

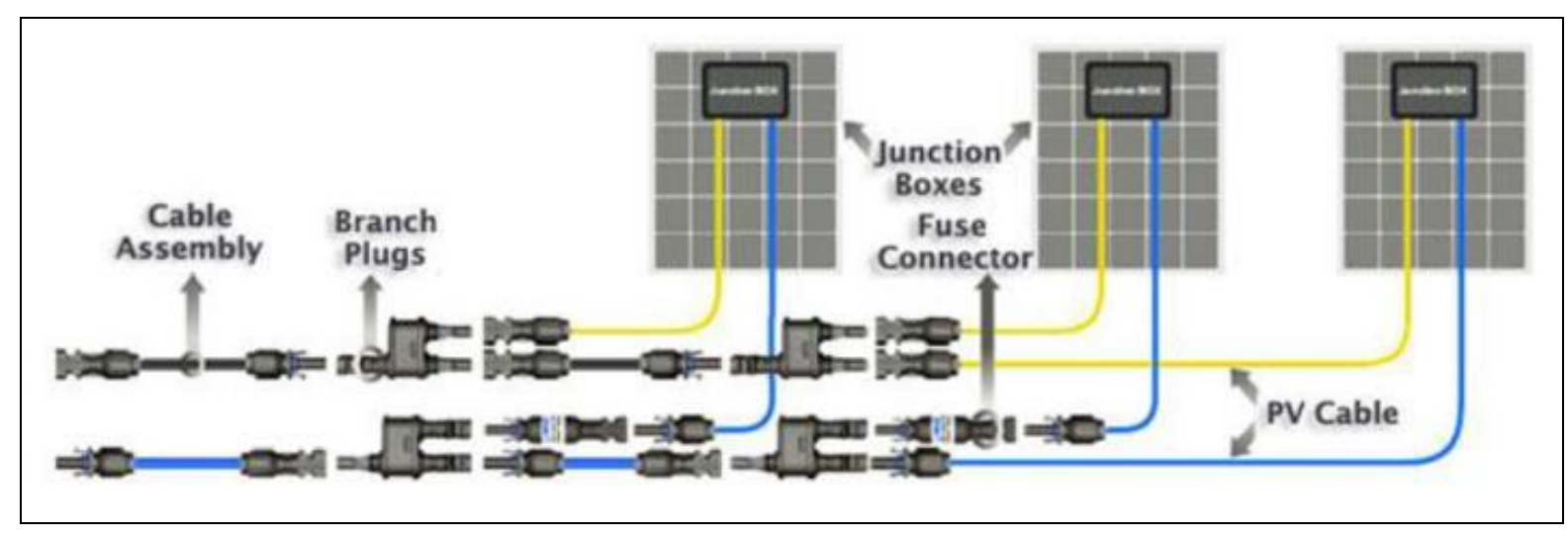

Figure 12: Solar junction boxes, connectors, and cable [65].

\subsection{Solar system operating principle}

Pumping water through PV technology is the process in which solar energy is converted to electricity in solar modules for water pump operation that is powered DC or AC motor [23].

\subsubsection{Solar energy}

Energy used by photovoltaic modules is generated from the sun. But only part of solar energy produced by the sun is absorbed by the panels. The whole amount of solar radiation produced cannot reach the ground. This quantity decreases as it moves through the atmosphere. A quantity is lost by the uptake of sunlight by the various atmosphere's molecules and also by the reflectance and by backscattering of sunlight due to dust, air particles, water vapor, etc. It is estimated at about 83\%, the radiation that reaches the ground on clear days [66]. However, solar radiation absorbed or scattered by the atmosphere in cloudy weather is $70 \%$ or less of global solar radiation [67]. In fact, the solar energy that reaches a PV solar field on the surface of the earth is composed of the direct radiation within the main beam and from the diffuse irradiance. The diffuse irradiance is made up of the incoming solar radiation subjected to atmospheric absorbance and the indirect irradiance [68]. In fact, energy irradiance corresponds to the global quantity of solar radiation incident on a horizontal surface. This energy results both from scattered and direct sunlight. It represents the horizontal global irradiance (GHI). GHI represents a critical parameter for solar PV applications [69]. However, the solar radiation that hits the Earth's outer atmospheric layers is characterized by a specific spectral configuration. The highest intensity between wavelengths is situated between $0.3 \mu \mathrm{m}$ and $4 \mu \mathrm{m}$ (visible wavelengths) [70]. The energy intensity of the extraterrestrial spectrum is estimated at $7 \%, 47 \%$, and $46 \%$, for ultraviolet wavelengths, visible, and infrared wavelengths, respectively [71].

The GHI changes considerably depending on geographical location [54]. Thus, the orientation and tilt angle of the solar panel are crucial to photovoltaic energy production [69]. Various angles are possible from the solar radiation insulation provided on Earth. These angles fluctuate in response to the orientation of the sun. In fact, since the Earth revolves around the Sun, the position of the Sun changes according to the longitude and latitude of the concerned site. As a result, the solar angles will be different for several places over the same period. The angle of inclination is a critical parameter for PV panel installation, as the operating efficiency of the PV panel varies with sunlight exposure [72]. The amount of incident radiation is maximum on the equatorial line due to the angle of incidence equal to zero which leads to sunlight intersecting the minimum distance through the atmosphere [73]. Therefore, photovoltaic panels in the northern hemisphere have to face south, and north when the site is located in the southern hemisphere [74], [74]. By convention, the best angle of inclination is equivalent to the latitude of the location where solar panels are installed. Thus, the local atmospheric conditions, the altitude of the area, the movement of the sun, etc. characterize the optimal angle of inclination of solar panels in a given area [69]. 


\subsubsection{Solar panel operating principle}

The production of electricity in a solar system occurs at the level of the solar photovoltaic cells [75]. Photovoltaic cells contain a semiconductor material that enables the conversion of sunlight into electricity [76]. The movement of electrons between the silica layers causes a voltage difference in the circuit, which allows the generation of electricity [52]. Indeed, when sunlight (photons) strikes a photovoltaic cell stimulation of negatively charged electrons occurs in the cell layers. This stimulation allows the movement of electrons from one layer to another, which results in the production of electric current. Thus, the electric current can then be used to provide energy in a given system by connecting the cells to an external charge [76].

The direct current produced by solar photovoltaic cells is a function of the total incident solar irradiation. There is a typical relationship between the sunlight striking the photovoltaic cells and the output current and voltage. In addition, the orientation of the system, shading, and sunlight of the location strongly influences the electrical energy produced. PV power generation is also a function of the operating temperature of the PV cells. The output power decreases with increasing temperature [77]. The performance of silicon photovoltaic cells may achieve $24.1 \%$ with monocrystalline panels [78]. Indeed, solar cells are characterized by four parameters which consist of " fill factor (FF), open-circuit voltage (VOC), short-circuit current (ISC), and peak power (Pmax)". They are considered as factors for evaluating photovoltaic cell efficiency. From a theoretical point of view, the current moves in the circuit when the panels are in the short-circuited state. Thus, the maximum output current produced corresponds to the ISC state. ISC is proportionally dependent on solar radiation and the size of solar cells [54].

\subsubsection{Solar pump operating principle}

Photovoltaic panels are associated with an AC or DC engine in which the electricity produced by the panel is transformed in mechanical energy, which in turn is changed into hydraulic energy within the pump [22]. Energy of the sun's rays translated into electrical energy through photovoltaic cells is the basic principle underlying the solar water pumping system. The electricity produced by the solar cells is used to operate the pump to raise water from the ground level or deep well. During the operation of the pumping system, solar energy can be stored in batteries in the form of chemical energy allowing the pumping system to operate at night in the absence of solar radiation. This is because the intensity of solar radiation is the most significant factor that limits the effectiveness of the solar water pump [51].

The ability to pump water from solar pump stations are based on three major variables. These are flow rate, pressure, and pump power [22], [79]. Pressure can be referred to the work that a pump must do to raise a specific amount of water [22]. The work that a pump must undertake is based on the difference in elevation from the water source to reservoir. Pump will extract as much water as the photovoltaic installation will provide much power [22]. In addition, according to Callahan and Waterman [79], the factors affecting the pressure required to flow the water are the altitude variation from the source of water and its final destination, the topography, the diameter of the pipe, and the water flow. Additionally, the water flow rate is the water quantity moved by a system during a specific period of time. Flow rate declines in proportion to the increase in pressure. The pump power is the quantity of energy consumed based on the pressure that must be produced to supply water. It is essential to provide the amount of energy necessary to move the water when dimensioning a photovoltaic panel by adding more PV than necessary. This allows the pump to operate early and later during the day or in low light conditions but having additional PV power may not boost water flow during high sunlight conditions. In addition, solar pump operating principle is variable from one pump type to another.

\subsection{Technical and economic feasibility of solar irrigation pump}

There was considerable growth in studies on the technological feasibility and economic sustainability of solar pump irrigation in several world regions between the 1980s and 1990s. However, it was not until the beginning of the 2000s that solar pumps became the focus of political interest in accordance with the growing discussion regarding alternatives clean energy [42].

\subsubsection{Technical feasibility of solar pumping for irrigation}

Various factors are taking into account for solar irrigation pumping system implementation. The technical feasibility of solar irrigation pumps depends on the maximum power required for irrigation, which in turn depends on the type of crop and the geographical location of the region for which the solar pumping device for irrigation will be implemented [80]. In fact, many factors must be taken into account for the optimal design of a Photovoltaic system in order to provide the maximum accuracy for a specific location. These factors can be arranged into three groups of variables, which are: “(i) physical variables, including plant and soil type, irrigation system specifications, PV system size, site attributes, (ii) climate, such as solar radiation, atmospheric 
temperature, relative humidity, wind speed, precipitation and (iii) management (irrigation schedule) to achieve the necessary reliability of the PV system" [23], [81]. A photovoltaic pumping system can be installed in several environments that meet a number of conditions. This refers to the existence of sufficient solar radiation and adequate areas of land that are not shaded for PV panels and infrastructure for water supply like reservoirs, in addition to sufficient water for crop irrigation [82]. Chandel et al. [22] found that solar pumping capacity is affected by factors including the head $(\mathrm{m})$ that raises pumped water $\left(\mathrm{m}^{3}\right)$, pump energy $(\mathrm{kWh})$, the efficiency of the system $(\%)$, and the daily change in pressure caused by radiation and fluctuations in pressure in the pump, crop water demand, reservoir size, and the technological efficiency of the photovoltaic panels. In addition, the length of pipes and flow rate are decisive in determining the pumping capacity required for irrigation. The higher insolation rate leads to a larger rate of water evaporation. Furthermore, the higher the water evaporation rate, the higher the capacity of irrigation due to the increase in pumping hours. At the same time, the higher the energy irradiance rate, the more energy photovoltaic panels will produce. Consequently, the peak power requested for irrigation is correlated with the peak solar energy available [44]. The area covered by the solar panels increases considerably with the depth of the wells and the daily water requirements of the crops in regions with low amounts of sunshine [83], [82].

For this purpose, based on solar radiation required for solar irrigation system operation, it emerges that solar pumping system is feasible technically in regions where the mean daily sunshine is between $4 \mathrm{kWh} / \mathrm{m} 2$ day and $5 \mathrm{kWh} / \mathrm{m} 2$-day in the summer period. In principle, daily mean irradiation intensity which is a minimum of $4.0 \mathrm{kWh} / \mathrm{m} 2 /$ day and more than $3.5 \mathrm{kWh} / \mathrm{m} 2 /$ day in the lowest month of sunlight is necessary for a solar pumping system to be feasible [83]. Solar energy usage in irrigation is efficient and very suitable for African regions, particularly in North and Sub-Saharan Africa. The solar pumping network provided up to $20 \mathrm{~m}^{3} / \mathrm{day}^{\text {in }}$ Nigeria, which was considered satisfactory for the population [25]. Photovoltaic pumps provided sufficient water to the small agricultural plot of less than 2 ha in Algeria [25]. In addition, the use of this energy technology when pumping water is very suitable in semi-arid and arid regions because of their enormous potential for solar energy. It is estimated at 3900 hours of sunshine per year in the Sahara and at $2263 \mathrm{kWh} / \mathrm{m}^{2} / \mathrm{year}$ of energy radiation in the southern part of the country. In addition, these areas have low groundwater recharge potential and irrigation water demand is at its peak in hot, dry weather coinciding with the time when the maximum solar energy is recorded [84]. Additionally, most of South Asia, Africa, South-East Asia, and South America countries have significant solar energy potential, however, the availability and depth of water resources vary considerably [85]. Rahman and Bhatt [86] conducted a study on the scope of solar energy in groundwater pumping in eastern India. The study showed that the nominal power of the network varied between 1.8 and 2.5 $\mathrm{kW}$ from 9:30 am to 2:30 pm. Also, they showed that a $3 \mathrm{hp}$ (horsepower) pump can be operational for 5 hours with solar energy of $3000 \mathrm{Wp}$ (Wp is watt peak; it is the power under controlled conditions of sunlight and temperature) in this area. At the end of this study, they concluded that a $1000 \mathrm{Wp}$ network is required for the operation of a $1 \mathrm{hp}$ underground pump in the eastern part of India. Maurya et al. [23] add that 1,300 to 2,600 liters of water per hour can be a move by a pump of 12 volt which is powered by a 50-watt photovoltaic solar panel. A considerable improvement in the pumping capacity of solar systems has been observed between 2010 and 2018. Solar pumps can deliver water to depths up to 500 meters below the water table with a flow rate of $500 \mathrm{~m} 3 /$ day, thus competing with polluting pumps operating with conventional energies [85].

Concerning solar irrigation pumping system design, Hadidi and Yaichi [84] show that for the proper functioning of the solar pumping system, it is important to make a good determination of the total daily monthly irradiation $\mathrm{kWh} / \mathrm{m} 2 /$ day in relation to the latitude of the work area, to choose the pump according to the flow rate and the total head, to choose an inverter according to the voltage and power of the pump, to determine the maximum photovoltaic generator power and the module's number, as well as the number of panels implemented in series and/or parallel required for the operation of the pump. The electrical, design, and orientation characteristics, as well as the environmental factors, must be considered when designing a solar pumping system because the irradiation converted by the panels is strongly dependent on these factors. Proper voltage and current are produced when the insolation has remained constant over a long period of time. However, the current decreases when there is a change in insolation while the terminal voltage remains constant. Indeed, the net voltage output of the modules is the sum of the single voltages and the resulting current output remains constant, when implementing solar modules in series. However, when they are arranged in parallel, the terminal voltage remains unchanged, while the net output current will be the added sum of the current of each panel. The net power delivery by the solar panels must be the result of the total output voltage and the current produced [87]. Several PV panels together may be coupled in series or in parallel to obtain the requested grid current and voltage through the effect of solar radiation. The optimal PV panel configuration is $2 \times 2$ panels and $2 \times 1$ panel for a $300 \mathrm{~W}$ and $130 \mathrm{~W}$ pump respectively. The efficiency is $12.5 \%$ and $12 \%$ for the $300 \mathrm{~W}$ and $130 \mathrm{~W}$ pump respectively in this case [43]. Also, different PV panel configurations allow optimizing the solar powered helical pump efficiency which supplies a flow estimated at $22 \mathrm{~m} 3 /$ day. Some test findings suggested an optimal

Page 11 of 22 
arrangement of the $8 \times 3$ and $6 \times 4$ modules. A software algorithm for the estimation of the solar PV pump capacity was developed for various photovoltaic arrangements [43]. Results showed the most appropriate $7 \times 3$ and $7 \times 4$ panel settings to operate a $750 \mathrm{~W}$ solar pump with $30-35 \%$ efficiency of the PV field implemented in Algeria [43]. Also, Benghanem et al. [88] investigated the optimal configuration of a photovoltaic grid to power a helical pump using an optimal energy amount in Saudi Arabia. Test was carried out on four configurations. The configurations were carried out as follows: (i) 6 series $\times 3$ parallels, (ii) 6 series $\times 4$ parallels, (iii) 8 series $\times 3$ parallels and (iv) 12 series $\times 2$ parallels. The results obtained following the study showed that the 6 series $x 4$ paralleled and 8 series $\times 3$ paralleled configurations provided the best performance, corresponding to a maximum daily average water volume of $22 \mathrm{~m}^{3} /$ day.

In addition, it is important to find a way to satisfy irrigation water requirement during the period of low sunshine. In fact, pumping hours are most often insufficient or even non-existent during certain periods in areas where there is a low number of hours of sunshine and very frequent cloud cover. For example, it is important to use a reservoir to meet irrigation water needs when climatic conditions are not favorable for solar pumping [88] [42],[89]. According to Wazed et al. [25], it is recommended for low flow pumps to use diaphragm pumps with direct current motor, while it is preferable to use centrifugal pumps with tilting motor for high flow pumps. Also, for delivery heads above 50-150 m, helical pumps can be used. Also, the photovoltaic system can be used in conjunction with an existing electricity grid. It can also be used in conjunction with batteries that store usable energy during periods of low sunlight. The photovoltaic system connected to an electrical grid can be equipped with batteries to operate the system when the electrical grid is down [90].

Additionally, an important factor in PV system operation is the degradation factors. In fact, the low irradiation conditions represent a major problem for the conversion of electrical energy by photovoltaic panels. Also, the amount of electrical energy generated by the photovoltaic field undergoes a continuous change with the weather conditions [50]. Environmental factors such as high temperature, dust, snow, and falls are a major problem for the operation of solar panels. These factors can negatively affect the effectiveness of the panels. Thus, an appropriate location of the panels is essential when installing the solar pumping system [87]. According to Chandel et al. [22], temperature, humidity, system polarization effects, and solar radiation play a major role in the degradation of photovoltaic modules. In fact, Schnetzer and Pluschke [82] showed that the optimal performance of photovoltaic panels decreases by $45 \%$ for each $1{ }^{\circ} \mathrm{C}$ increase in temperature over $28^{\circ} \mathrm{C}$. In addition, several other factors have a negative effect on the performance of a solar photovoltaic system. Indeed, a maximum 35\% decrease in efficiency is reported for a network layout that includes two shaded panels in each line. PV panel performance is also deteriorated due to extended PV system operation. For example, it is reported that about $45 \%$ of the solar pumping systems in Thailand have failed due to continuous operation [43]. Also, the degradation of the photovoltaic modules negatively impacts on the efficiency of solar pumping device. It has been estimated that the degradation rate of monocrystalline modules in India is about $1.4 \%$ per year. However, even after 28 years of operation, the solar system was able to generate enough energy to extract water with an average flow rate estimated at $829 \mathrm{l} / \mathrm{h}$ [91]. In addition, polycrystalline silicon panels have a lower deterioration rate than single-crystalline silicon panels [22].

According to the UNICEF [92] report on the scale-up of solar-powered water supply systems, the solar pumping system is very sustainable. Indeed, solar pumping systems can last up to 10 years when properly placed and installed. The pump itself has a life span of between 5 and 15, the solar panels have a life span of about 25 to 30 years and the control panels generally have an average life span of about 7 years. In addition, solar pumping systems require little maintenance.

\subsubsection{Economic feasibility of pump for irrigation}

Economic is the most important factor that influenced the expansion of the large-scale PV pump irrigation system. It is also the key indicator that mainly concerns stakeholders. Different factors are using to evaluate the economic feasibility of solar pumping system. These factors are related to the investment cost, the Net Present Value (NPV), the Benefit Cost Ratio (BCR), the Internal Rate of Return (IRR), the Payback Period (PBP), and the Life Cycle Cost (LCC).

Concerning the investment cost, Gao et al. [93] showed that the investment cost of the diesel powered system was actually lower than that of the PV pump irrigation system. Nevertheless, the cost regarding operation of the PV irrigation pumping system (900 CNY (Chinese Yuan)/year) was much lower compared to cost of operation in the case using of diesel pump (7900 CNY/year). The solar powered pump system's cost for irrigation depends on the required photovoltaic capacity, import taxes for photovoltaic solar energy and related equipment, and the requirements and dimensions of water storage or battery storage facilities [82]. Niajalili et al. [44] investigated the cost regarding PVP and traditional pumping systems during their lifetime in Iran. They found that the Investment capital of PVP is approximately 7 times higher than that of a traditional pump implementation. This represents the biggest obstacle to the use of PVPs (Photovoltaic pumps). However, it is 
also noted that the total costs of both PVC and traditional systems are equal over about 9 years of operation. They also showed that the life cycle costs of PV pumps are 1.56 times lower than those of traditional pumps after 25 years operation period. Consequently, using photovoltaic pumps is both economically feasible and reasonable. Das and Toppo [94] conducted a feasibility study on a nano-solar pump with a gravity drip irrigation system for vegetable cultivation in Krishi Vigyan Kendra Gajapati in India. The study showed that the initial investment of a solar nano pump was high compared to other systems. The cost of the solar nano pump with an average life of 15 years was estimated at 18,000 rupees. Thus, it was recommended to grow crops such as onion, capsicum, and broccoli, which have a recovery period of nearly 5, for a faster return on the initial investment [94]. In the United States of America, the investment cost of photovoltaic panels is estimated at between 2500 and $3000 \mathrm{USD} / \mathrm{KW}$, while it varies between 500 and $800 \mathrm{USD} / \mathrm{KW}$ for fuel pumps, which reflects the high investment cost [82]. In 2012, the investment cost of a photovoltaic solar power plant composed by the PV module, grid connection inverter, cabling, and settings was estimated at USD 3400/kW in Turkey [95], [96]. In fact, the implementation price of solar PV pump changes according to the depth of the wells, the productivity of the pumping system, the energy demand, and the piping [90]. According to Anoop and Reema [87], the investment price regarding the solar irrigation pump is more expensive. However, the cost of maintenance and operation is much cheaper. In addition, the cost related to the investment when implementing photovoltaic water pumping system was approximately 2.41 larger than the investment cost of diesel pump. However, the operation and maintenance costs and the total life cycle cost were respectively 7.25 times and $16 \%$ smaller than those of diesel pump. In addition, Curtis [90] estimated at $0.89 \%$ of the investment cost, the annual maintenance, and at 30 years lifetime of the photovoltaic panel. Nerveless, the high cost of the initial investment is a constraint to its adoption, particularly in rural areas. However, it is likely that the profitability of the photovoltaic pumping system will increase in the future due to lower photovoltaic panel prices and higher oil prices.

According to Hossain et al. [97], in Bangladesh, the cost of modules is more important (45\%) when considering the solar pumping system, followed by the implementation, the whole pump, and other accessories costs, representing $18 \%$, motor $26 \%$ and $4 \%$ of the total cost, respectively. They demonstrate that the cost of fuel pumps is under the cost of solar over a five (5) year period in Bangladesh. However, the cost diesel pump has increased and was higher from five years until the end of the lifespan of solar pump. The high cost of panels considering the investment cost show that an optimal panel sizing is important for the system to be economically viable. Thus, selection of a pump with a subsystem efficiency of about $70 \%$ can lead to a reduction in panel size, also leading to a reduction in cost [42]. In fact, between 1998 and 2014, an average decrease of 6\% to $12 \%$ in the prices of PV systems was estimated per year in Turkey. Also, Photovoltaic system prices have fallen by about $10 \%$ on average from 2014 to 2015 [98]. Also, in recent years, there has been a decrease in the cost of solar energy as fuel costs rise from day to day. It has been predicted that over the next four years, the cost of solar energy will be half the cost of fuel used in pumping [46]. A 75\% drop in the price of photovoltaic panels is expected in 2020 in reference to panel prices in 2010 in the United States [99]. According to Garg [100], the use of the solar pumping system has proven to be very advantageous from an economic point of view. However, constraints such as expensive investment capital, low post-implementation support, and limited awareness of these benefits are limitation to its adoption in India. The trend of declining module prices is seen as a tool that can reduce dependence on conventional pumps that are expensive for producers. It is estimated that in India the cost of energy used for irrigation is 18 million rupees, supplying a network of nine hundred thousand tube wells. However, this high cost of electricity can be reduced with the use of solar energy. Indeed, solar energy reduces the energy used per year by 5 million $\mathrm{kWh}$, corresponding to 27 million rupees saved per year. This amount saved corresponds to $40 \%$ of the investment cost of solar irrigation pumps, which makes it possible to recover the total investment of solar irrigation pump cost in less than 2 years, which is quite high. Thus, it is possible to economize up to 4.8 million kWh of energy annually through the use of solar energy for irrigation, which can be fed into network through small adjustments and improvements in the system, thus increasing the farmer's income [101]. Also, a saving equivalent to $760 \mathrm{MW}$ electrical energy and 8 billion liters of diesel fuel per year is possible in Bangladesh's rice fields through the use of solar irrigation pumps [102]. Replacing one million solar pumping systems with traditional pumping system results in $\$ 300$ million less in diesel fuel imports annually, saving $\$ 4.5$ billion over the life of the pumps [103].

Based on Mekhilef et al. [104], a comparative study of solar, electric, and fuel pumping systems showed that the electric pumping system has a higher investment and operating and maintenance cost. After 10 years of operation, it has been shown that electric and solar irrigation systems are more profitable because the fuel pumping system requires more change. Use of solar pump in irrigation is considered as better alternative for isolated rural areas at an affordable price when considering a life cycle of 25 years. In India, the number of farmers earning more than 100,000 rupees has increased from $26 \%$ to $58 \%$ through the use of solar irrigation pumps. As well, $45 \%$ of farmers had an increase of more than $50 \%$ in their annual income and $70 \%$ beg an to earn $25 \%$ more. In addition, the cost of water paid by producers for irrigation ranged from Rs. 7,000 to Rs. 
80,000 , depending on the capacity of the pump, the district, and the procurement program through the existence of generalized subsidies. This cost was lower than the annual cost of irrigation water from the direct purchase or installation of a diesel pump [11].

Indeed, invest in solar pumping system is more profitable because BCR, NPV, and IRR were higher compared to those of conventional pumps. Nikzad et al [105] investigated the economic, technical and environmental modeling of a solar irrigation pump for rice production in Iran. The results showed that the cost related to the investment when implementing photovoltaic water pumping system was approximately 2.41 larger than the investment cost of diesel pump. However, operating and maintenance expenses and total life cycle cost (LCC) were 8.7 times and $29.9 \%$ lower than those of conventional pumps, respectively. Also, Copeland [106] conducted a study on solar irrigation pumps in Zambia in Shamiyoyo. Results indicated that using solar pumps in irrigation is economically advantageous in Shamiyoyo. Indeed, the leveled cost of energy (LCOE) for solar energy was lower than that for gasoline. The LCOE for small-scale solar energy was $\$ 0.15 / \mathrm{kWh}$ compared to $\$ 0.20 / \mathrm{kWh}$ for an alternative gasoline engine. Although the difference was not significant, it was considered economically massive for low-income communities [106]. Also, Narale et al. [107] carried out a technical and economic assessment of a solar pumping system in India. It emerged from this study that PV water pumps are more costly than fuel pumps based on the capital investment. However, a decrease in the recurrent PV system cost was observed for a period of 20 years because of the lowest operating and maintenance expenses and its longer service life. Thus, it was estimated at $€ 35,117.47$ and $€ 8,649,669.00$ LCC for PV pump and diesel engine over a 20-year period. In addition, NPV, IRR, and PBP was evaluated at $€ 209366.79,29.64$ and 2.17, respectively over a 20-year period when using solar pump. EL-Shimy et al [50] demonstrated that solar energy usage when pumping water for irrigation water is more economical than the use of conventional energy in Egypt. Indeed, the LCOE varied between 0.071 and 0.067 (\$/kWh) in the case of solar pump use. However, it varied between 0.220 and $0.210(\$ / \mathrm{kWh})$ for the diesel pump and is estimated at $0.190(\$ / \mathrm{kWh})$ with the electric pumps. In Senegal, the cost of operating and maintaining solar irrigation pumps is very low. It is estimated at $2 \%$ of the initial investment, whereas it represents $10 \%$ of the initial investment in the case of diesel-powered pumps. Also, the use of solar irrigation pumps can reduce LCOE by $30 \%$ compared to the diesel pumping system [108]. According to Hammad and Ebaid [109], solar pumping system is more cost-effective in economic terms. Life cycle costs over 25 years were US\$ 0.136, 0.140, 0.144, 0.185, and $0.239 / \mathrm{kWh}$ for PV, PV-grid, grid, PV-genset, and genset respectively.

Ali [110] conducted a study on the reliability of using solar pumps for irrigation in Sudan. The study consisted to compare a "parabolic trough pump" (PTP), a "flat concentrator pump" (CDP) and a "photovoltaic pump" (PVP). Results showed that the photovoltaic pump was more cost effective. It was estimated at $\$ 1351 / \mathrm{kW}, \$ 4072 / \mathrm{kW}$, and $\$ 4884 / \mathrm{kW}$ the unit hydraulic power price of a PVP, CDP and PTP, respectively. A study by Bakhsh et al [111] on solar powered tube wells and their agricultural applications showed the recovery period regarding the investment was 2.2 years and the internal rate of return (IRR) reached $41 \%$ over 10 years life. Also, BCR for was estimated at 2.77, 2.55, 2.36 and 2.19 for discount rates of 2, 4, 6 and $8 \%$ respectively and NPV was also evaluated at 1.39, 1.19, 1.03 and 0.88 million rupees for discount rates of 2, 4, 6 and $8 \%$ respectively when using solar tube wells. As a result, the solar-powered tube well is a viable option. The operating cost of solar systems is significantly smaller than that of diesel-powered irrigation systems over a five-year period. Thus, it is possible to save $50 \%$ of the water costs per $\mathrm{m}^{3}$ by using the solar pump for irrigation with a return on investment in only 3 years [112]. Lorenzo et al. [113] presented an economic evaluation of large-power solar systems (ranging in few dozen to a few hundred $\mathrm{kWp}$ ) in ECOWAS zone, taking into account the necessary investments relative to the implementation. Results show that the Net Present Values is between $\$ 0.33 .5 \times 10^{5}$ and $\$ 41.5 \times 10^{5}$. The Internal Rate of return founded are superior to the internal discount rate which is between 8 and 47\%. The Payback period ranges from 2.1-10 years with a lifetime of 25 years of the system. In addition, the Levelized Cost of Electricity values is the cheapest for solar pump varying from $\$ 4.5$ to 17.4 cents/kWh, indicating a very large amount saving of between 30 and $84 \%$, compared to conventional pumping systems. In Senegal, the payback period for solar pumps is estimated at between 2 and 2.5 years in the belt between Dakar and Saint-Louis (3 horticultural crops per year for urban markets, 1 ha of irrigation, 15\% interest on the equipment) [39]. In addition, Abric [15] conducted a study on solar irrigation in the Niaye region in Senegal. The results showed that the solar irrigation solutions (manual drilling, solar pumping, and water application) tested were profitable for vegetable production. In fact, low water production costs have resulted in a very rapid return on investment (about 2 to 3 campaigns). However, the initial acquisition cost remained high (1.5 to 2.5 million CFA / 2585 to 4374 USD). Also, the study showed that the replacement of the pump represents around $20 \%$ of the cost of the solar solution, whose lifetime will be less than or equal to 4 years depending on the conditions (pumping time, water quality). It was concluded that it is important to encourage farmers to finance their renewal and to keep the cost of the pump as low as possible. In fact, this study demonstrated that solar pumps made in China, which are three times cheaper than their European competitors, 
are of particular interest to small producers because of its low cost. The cost of a solar pump without financial support, based on a lifespan of 10 years, represents $64.2 \%$ of diesel pump prices in India. In addition, Chandel et al. [22] demonstrate that use of solar pump in India is more cost-effective compared to irrigation and water supply systems using electricity or diesel in rural, urban and remote areas. He estimated PBP for some solar water pumping to be achieved after 4 to 6 years. Some authors have pointed out that if the tracking device is capable of providing better efficiency, the fixed-sensor device is usually more cost effective. On the opposite, it has been reported that it is possible to achieve a cost reduction of $19 \%$ with the tracking system and $48 \%$ with the concentration system as opposed to a fixed sensor system. In addition, it is also indicated that the use of Vtrough concentrators is the most cost-effective method when the solar pump is used. This could reduce the cost by $48 \%$ [43].

In addition, Bolaños et al. [114] also investigated solar feasibility when using various techniques to irrigate in Colombia. Their results showed that there are no significant differences in cash flow results for sprinkler irrigation, and drip irrigation systems. However, they demonstrated that the cash flow of surface irrigation by solar pumping was very high in this case, the higher pumping costs are caused by a larger size of the PV installation. Furthermore, Hossain et al. [115] performed research in Bangladesh using a solar pump with drip, furrow and flood techniques for growing brinjal, tomato, wheat and boro rice. The results showed that the water savings in the case of drip to irrigate brinjal was estimated at $53.25 \%$ and that of tomato was equal to $56.16 \%$. About $430 \mathrm{~mm}$ of water was required to grow wheat and yield of $3.00 \mathrm{t} / \mathrm{ha}$ resulted from this. The water requirement for growing boro rice in Magura and Barisal amounted to $1024 \mathrm{~mm}$ and $1481 \mathrm{~mm}$ respectively. The solar irrigated wheat, tomato and brinjal crops have been cost-effective, in the opposite of boro rice because of the large amount of water required.

\subsection{Environmental impacts of solar irrigation pump}

Photovoltaic solar power units (PVPS) represent an ecological, economical, and low-maintenance alternative to pumping units that run on electricity or diesel [23]. From an ecological point of view, it is much more environmentally friendly than any generators using conventional energy sources. The PV pump is an ecological and non-polluting irrigation technology that reduces CO2 emissions [97][100]. Photovoltaic solar energy is a possible alternative to reducing the irrigation sector's energy dependence on diesel and grid electricity [116].

In 2010, energy use in the agricultural sector was responsible for the emission of 785 million tons of CO2 into the atmosphere, corresponding to almost one-fifth of total global $\mathrm{CO} 2$ emissions. Because of the environmental damage caused by the use of conventional energy, renewable energy is being promoted as a new, proper and reliable auxiliary energy source in the agricultural sector [117]. In India, there was a potential reduction in GHG emissions in 2000. This reduction was induced by the substitution pumps using traditional energy for pumping groundwater with photovoltaic pumps. Annual carbon emissions have been estimated to be in the range of 59 to $92 \mathrm{Mt} \mathrm{CO} 2 \mathrm{e}$, representing 4 to $6 \%$ of total national CO2 emissions in 2000 in India [82]. Also, 5.2 and 4 tons of $\mathrm{CO} 2$ are emitted each year by diesel and electric pumps with a capacity of 5 HP and operating 1250 hours per year respectively. A reduction of 26 million tons of CO2 per year is possible in India by replacing 5 million diesel pumps with solar pumps, representing $1.2 \%$ of global amount of CO2 released in India during the year 2010 [42]. Aliyu et al [43] have shown that solar photovoltaic energy is a possibility of mitigating climate change and water savings. An economic life cycle was conducted to determine the quantity of $\mathrm{CO} 2$ releases directly or indirectly by solar pumps. Approximately $3,744 \mathrm{~kg}$ of CO 2 is produced by the diesel pumps. The functioning of diesel engine is very noisy and contaminates the environment. But the PV powered engine is an environmentally friendly and non-polluting pumping system. Also, the number of irrigation pumps increased between 1990 and 2012, from 0.33 million to 1.81 million. At the same time, CO2 emissions generated by irrigation pumps accounted for 1.43 million tones and 6.73 million tonne in 1990 and 2012 , respectively. These results allowed them to assume that diesel irrigation pumps pollute the environment while solar pumps are environmentally friendly [115].

SPIS provides a significant greenhouse gas (GHG) emission mitigation capability. Water pump functioning in the SPIS is exempt from GHG releases. GHG emissions sources when using solar irrigation pump are recorded when manufacturing and destroying the photovoltaic panels. The assessment of gas emissions over the life cycle of solar systems indicates a potential reduction of 95 to $97 \%$ in the amount GHG released for each energy unit consumed to pump water $(\mathrm{CO} 2-\mathrm{eq} / \mathrm{kWh})$ when compared with pumps running on grid electricity. In addition, the decrease in the quantity of GHG emitted from each unit of energy utilized compared to diesel pumps is estimated at 97 to $98 \%$ [82]. Thus, renewable energy resources are very advantageous from an environmental point of view.

They reduce dependence on fossil fuels and GHG emissions to the atmosphere [118]. Also, he shows that solar irrigation pumps reduce greenhouse gas emissions by $70.5 \%$. Paulsen [119] add that solar pumping systems have made a significant contribution to reducing air pollution by reducing the use of fuels in pumping

Page 15 of 22 
that cause GHG emissions. They also conserve groundwater by reducing water consumption. This reduction is due to slower groundwater use over a given period of time, compared to pumping with fuel. Solar water pumps reduce emissions of environmentally harmful particles, prevent diesel leaks from crops and water, prevent noise pollution, and contribute to more efficient water use. The replacement of renewable energies by fuels reduces $\mathrm{CO} 2$ emissions by $2.5 \mathrm{~kg}$ per liter of diesel [120]. The use of solar pumping technology reduces the use of conventional energy and therefore reduces the impact of global warming and mitigates the negative effects of conventional energy use on air quality [81]. In the climate change context, SIPs provide the potential to mitigate greenhouse gas emissions and increase farmers' resilience to irregular precipitation that it induced [42]. The $\mathrm{CO} 2$ rate emitted by solar pumps is 13 and 3 times lower (in Morocco and Portugal) than the emissions caused by pumps powered by conventional energy. Indeed, the primary energy stored in the solar pumping system was $1284 \mathrm{MJ} / \mathrm{kWp}$ and $1317 \mathrm{MJ} / \mathrm{kWp}$ in the case of Moroccan and Portuguese implementations, respectively. Quantities of GHGs emitted by Moroccan and Portuguese installations were 78.8 and $81.6 \mathrm{~kg}$ CO2e per kWp respectively. The manufacture of photovoltaic modules accounted for $75 \%$ of the total energy incorporated. The implementation of the HPVIS system resulted in energy conservation estimated at about $41 \%$ in Morocco and $67 \%$ in Portugal, and avoided natural resource consumption and release of large amounts of GHGs into the atmosphere [121]. In addition, it is evaluated at $0.6 \mathrm{~kg}$ of $\mathrm{CO} 2 / \mathrm{kW}$ h the annual reduction of $\mathrm{CO} 2$ emission due to photovoltaic systems [122]. Emissions of 0.4 billion and 0.03 billion tons of $\mathrm{CO} 2$ can be avoided by replacing 1 million solar pumps with diesel or electric pumps respectively [123]. A saving of 9.4 billion liters of diesel fuel, resulting in a reduction in $\mathrm{CO} 2$ emissions of 25.3 million tons, can be achieved by substituting one million diesel pumps with solar pumps [124]. In Bangladesh, the government planned to implement 10,000 solar pumps for irrigation in 2016 to expand the area of irrigated land. This initiative aimed to optimize US\$1 billion over 20 years in combustible subsidies and reduce emissions by 126,000 tons of CO2 per year [125]. In Bangladesh, the installation of 2,000 solar PV irrigation pumps can eliminate 796,875 liters of diesel. This can result in a reduction of 2,160 tonnes of CO2 emissions per year, or 43,200 tonnes of CO2 over a 20-year lifetime. Indeed, producing 5,054 MWh/year of electricity with $5 \mathrm{HP}$ and 7.5 HP systems can result in additional emission savings estimated at 3,791 tons of CO2 per year or 75,810 tons of CO2 over a 20-year lifetime. These results are obtained using a conservative emission factor of 0.75 tonnes of CO2 per MWh 107 [126].

According to Kaya and Kose [99], replacing conventional energy with renewable energy in water pumping significantly reduces greenhouse gas emissions. In Turkey, it is estimated at $70 \%$, the electrical energy produced by natural gases and coal, while $\mathrm{CO} 2$ emissions from the combustion of coal and natural gas are respectively about 820 and $490 \mathrm{gCO} 2 \mathrm{eq} / \mathrm{kWh}$. Also, 1.2 tons CO2 equivalent released can be avoided in Spain by switching the electricity grid to a photovoltaic system with a maximum power evaluated at $15.4 \mathrm{~kW}$ during the whole irrigation campaign covering 602.3 hours [117]. The use of a combined solar, wind and hydraulic when making system for water extraction can reduce $\mathrm{CO} 2$ emissions by $1030 \mathrm{Mg}$ [130, 43]. In addition, it is reported that the release of 4.2 tons $\mathrm{CO} 2$ /year could be avoided by using 1000 photovoltaic systems of $1 \mathrm{~kW}$ pumps power [93], [43]. In India, it is estimated that saving 23 billion $\mathrm{kWh}$ of grid energy, or 10 billion liters of fuel consumption is possible through the implementation of 5 million PV pumps. This is equivalent to a decrease in 26 million tons in $\mathrm{CO} 2$ release. In addition, '450 million liters of diesel fuel and 1 million tons $\mathrm{CO} 2 / \mathrm{year}$ can be avoided through the establishment of 50,000 Photovoltaic pumping system in Bangladesh' [127].

Todde et al. [126] investigated the capacity of hybrid solar pumping systems in Mediterranean olive orchards. This study was carried out in Portugal and Morocco. The results showed that the Moroccan implementation accounted for about 236-ton $\mathrm{CO}_{2} \mathrm{eq}$, whereas in Portugal the system amounted to about 285ton $\mathrm{CO}_{2}$ eq. The larger quantity of $\mathrm{CO} 2$ emission regarding Portuguese implementation is principally caused by the insufficient usage of the irrigation network in unfavorable climatic conditions, cropping patterns, etc., and because of the necessity of using the diesel generator for irrigation at night and in other critical periods. In addition, García et al. [116] carried out an environmental comparison and economic effect of solar energy using on-grid and off-grid with conventional sources of energy for irrigation in farming systems. This study was carried out in Spain. The results showed that the life of the pump can have a positive impact on the environment. The environmental impact of the photovoltaic system has gradually decreased from 5 to 30 years, as the installation is the main source of negative environmental impacts. However, the magnitude of the environmental impact of the diesel generator and electricity grid, per kWh, has not changed significantly over the years, due to the fact that most of the impacts are related to the operating time. Also, the study showed that the addition of a grid connection to a photovoltaic installation allowed the use of the residual $80 \%$ of the electricity generated by the photovoltaic installation. Thus, in spite of the extra effect of cable and poles on the environment, a 54$77 \%$ reduction in environmental impact per $\mathrm{kWh}$ was observed. This reduction was possible by keeping a relatively close distance between the PV plant and the grid. A case study was also conducted in China's Inner Mongolia using a $3.4 \mathrm{kWp}$ solar system with a 20 year expected lifetime. Analysis results revealed an amount of $\mathrm{CO} 2$ released of $20,060 \mathrm{~kg}$ including $43.5 \%$ of the photovoltaic panels' emissions, in which $89 \%$ is caused 
by panel's manufacturing process. Also, it emerges from this study that $\mathrm{CO} 2$ emissions reduction from the use of solar pump is about $129 \mathrm{Mg} \mathrm{CO} 2 /$ ha [128].

Armanuos et al. [129] add that the impact of photovoltaic systems on the environment is not as significant as that of diesel systems. The estimated impact of diesel systems for water extraction on natural resources, climate change, public health, and on the quality of ecosystems is $70 \%, 10 \%, 18 \%$, and $2 \%$ respectively. In contrast, it is estimated at $3 \%, 2 \%$, and $0.5 \%$ the impact on human health and natural resources and ecosystem quality, respectively, when using solar pump.

\section{Conclusion}

Solar energy is considered a promising alternative energy source to conventional energy sources. Conventional energy sources such as fuel and electricity can be considered as inhibiting factors to the development of irrigation. These energy sources are most often used for water pumping. However, they are very expensive, and electricity is not always accessible, especially in rural areas. Various factors impact on the operation of solar pumps, among them the most important is solar irradiation. The different works carried out on solar pumping show that they can be used in many places in the world. The use of solar irrigation pumps is economically feasible, despite the high investment cost, perceived as a limiting factor to its adoption. In addition, the various studies show that the investment cost decreases over time due to the significant decrease in the cost of the panels and even the pump which promotes the use of solar energy for water pumping. A special feature of solar irrigation pumps is related to their low environmental impact. In general, the $\mathrm{CO} 2$ emissions related to solar pumps occur during the manufacturing and destroying of the solar panels. However solar pump don't have environmental impact during operation in contrast to diesel or electrical pumps. In addition, more in-depth studies can be carried out on solar pumping. In addition, more in-depth studies can be carried out on solar pumping. These studies can focus on the:

- degradation of solar pumping systems under the effect of high temperature.

- effect of dust on the efficiency of the solar pumping system.

- comparison between the efficiency of monocrystalline and polycrystalline solar panels in areas with high sunlight.

- $\quad$ economic feasibility of using solar pumping systems combined with battery for small farms in rural areas.

Conflict of interest: The authors declare no conflict of interest to any party.

\section{References}

[1] J. Bongaarts, "Human population growth and the demographic transition," Philosophical Transactions of the Royal Society B: Biological Sciences, vol. 364, no. 1532, pp. 2985-2990, 2009.

[2] U. N. Desa, "World population prospects 2019: Highlights," New York (US): United Nations Department for Economic and Social Affairs, 2019.

[3] UN, "Population 2030: Demographic Challenges and Opportunities for Sustainable Development Planning." UN, Department of Economic and Social Affairs New York, USA, 2015.

[4] A. Agarwal, A. Lubet, E. Mitgang, S. Mohanty, and D. E. Bloom, "Population aging in India: Facts, issues, and options," in Population Change and Impacts in Asia and the Pacific, Springer, 2020, pp. 289-311.

[5] A. Lem, T. Bjorndal, and A. Lappo, Economic analysis of supply and demand for food up to 2030 Special focus on fish and fishery products. Rome: Food and agriculture organisation of the united Nations, 2014.

[6] N. Alexandratos and J. Bruinsma, World agriculture towards 2030/2050: the 2012 revision, ESA Workin. Rome: FAO, 2012.

[7] FAO, Coping with water scarcity: An action framework for agriculture and food security. Rome: FAO, 2012.

[8] G. Oseni, K. McGee, and A. Dabalen, "Can agricultural households farm their way out of poverty?," no. November, p. 23, 2014.

[9] C. Thirtle, L. Lin, and J. Piesse, "The impact of research-led agricultural productivity growth on poverty reduction in Africa, Asia and Latin America,” World Development, vol. 31, no. 12, pp. 1959-1975, 2003.

[10] F. F. Nchuchuwe and K. D. Adejuwon, "The Challenges of Agriculture and Rural Development in Africa : The Case of Nigeria," International Journal of Academic Research in Progressive Education and Development, vol. 1, no. 3, pp. 45-61, 2012.

[11] AGRA, Africa Agriculture Status Report: The Business of Smallholder Agriculture in Sub-Saharan 
Africa. Nairobi, Kenya: Alliance for a Green Revolution in Africa (AGRA), 2017.

[12] F. C. McKenzie and J. Williams, "Sustainable food production: constraints, challenges and choices by 2050," Food Security, vol. 7, no. 2, pp. 221-233, 2015.

[13] C. Müller, W. Cramer, W. L. Hare, and H. Lotze-Campen, "Climate change risks for African agriculture," Proceedings of the National Academy of Sciences of the United States of America, vol. 108, no. 11, pp. 4313-4315, 2011.

[14] OCDE, Climate Change,Water and Agriculture: Towards Resilient Systems. OECD Studies onWater, OECD Publishing, 2014.

[15] S. Abric, Solutions de pompage solaire pour l'irrigation à des profondeurs intermédiaires pour les petits producteurs de la région des Niayes. PRATICA Founation, 2019.

[16] R. Sands et al., "Impacts of Higher Energy Prices on Agriculture and Rural Economies," U.S. Dept. of Agriculture, Econ. Res. Serv. August, no. 123, p. ERR-123, 2011.

[17] O. Edenhofer et al., "Renewable energy sources and climate change mitigation: Special report of the intergovernmental panel on climate change," Renewable Energy Sources and Climate Change Mitigation: Special Report of the Intergovernmental Panel on Climate Change, no. December, pp. 11075, 2011.

[18] P. A. Owusu and S. Asumadu-Sarkodie, "A review of renewable energy sources, sustainability issues and climate change mitigation," Cogent Engineering, vol. 3, no. 1, pp. 1-14, 2016.

[19] L. Calvet and F. Marical, "Consommation de carburant: Effets des prix à court et à long terme par type de population," Economie et Statistique, no. 446, pp. 25-44, 2012.

[20] A. Abdelkerim, M. . Eusuf, M. Salami, A. Aibinu, and M. . Eusuf, "Development of Solar Powered Irrigation System," vol. 53, 2013.

[21] IRENA, "Renewable power generation costs in 2017," Report, International Renewable Energy Agency, Abu Dhabi, 2018.

[22] S. S. Chandel, M. N. Naik, and R. Chandel, "Review of solar photovoltaic water pumping system technology for irrigation and community drinking water supplies," Renewable and Sustainable Energy Reviews, vol. 49, pp. 1084-1099, 2015.

[23] V. N. Maurya, G. Ogubazghi, B. P. Misra, A. K. Maurya, and D. K. Arora, "Scope and review of photovoltaic solar water pumping system as a sustainable solution enhancing water use efficiency in irrigation," American Journal of Biological and Environmental Statistics, vol. 1, no. 1, pp. 1-8, 2015.

[24] V. B. Shinde and S. S. Wandre, "Solar photovoltaic water pumping system for irrigation: A review," African journal of agricultural research, vol. 10, no. 22, pp. 2267-2273, 2015.

[25] S. M. Wazed, B. R. Hughes, D. O’Connor, and J. K. Calautit, "A review of sustainable solar irrigation systems for Sub-Saharan Africa,” Renewable and Sustainable Energy Reviews, vol. 81, pp. 1206-1225, 2018.

[26] M. R. Islam, P. C. Sarker, and S. K. Ghosh, "Prospect and advancement of solar irrigation in Bangladesh: A review," Renewable and Sustainable Energy Reviews, vol. 77, pp. 406-422, 2017.

[27] O. Dubois, The state of the world's land and water resources for food and agriculture: managing systems at risk. Earthscan, 2011.

[28] R. van Der Wijngaart, J. Helming, C. Jacobs, P. A. G. Delvaux, S. Hoek, and S. G. y Paloma, "Irrigation and irrigated agriculture potential in the Sahel: The case of the Niger river basin: Prospective review of the potential and constraints in a changing climate," Joint Research Centre (Seville site), 2019.

[29] S. Siebert et al., "Groundwater use for irrigation-a global inventory," Hydrology and earth system sciences, vol. 14, no. 10, pp. 1863-1880, 2010.

[30] M. F. Jusoh, M. A. M. Zawawi, H. C. Man, and S. Kamaruddin, "Performance of Shallow Tube Well on Groundwater Irrigation in Tropical Lowland Rice Cultivation Area," Sains Malaysiana, vol. 42, no. 8, pp. 1101-1108, 2013.

[31] S. W. D. Turner, M. Hejazi, C. Yonkofski, S. H. Kim, and P. Kyle, "Influence of groundwater extraction costs and resource depletion limits on simulated global nonrenewable water withdrawals over the twenty-first century," Earth's Future, vol. 7, no. 2, pp. 123-135, 2019.

[32] T. F. Scherer, "Irrigation water pumps," 2017.

[33] X. Chen, K. R. Thorp, Z. Ouyang, Y. Hou, B. Zhou, and Y. Li, "Energy consumption due to groundwater pumping for irrigation in the North China Plain," Science of The Total Environment, vol. 669, pp. 1033-1042, 2019.

[34] S. G. S. A. Rothausen and D. Conway, "Greenhouse-gas emissions from energy use in the water sector," Nature Climate Change, vol. 1, no. 4, pp. 210-219, 2011.

[35] N. Argaw, R. Foster, and A. Ellis, "Renewable energy for water pumping applications in rural villages," New Mexico State University Lass Cruces, New Mexico, 2003. 
[36] M. Ritchie and M. Roser, "Energy," 2020. .

[37] USDA, Part 623 Irrigation National Engineering Handbook : Irrigation Pumping Plants. 2016.

[38] SELF, A cost and reliability comparison between solar and diesel powered pumps. 2008.

[39] S. Linn and A. Z. Ya, "Solar/wind/diesel hybrid energy system with battery storage for rural electrification,” Int J Sci Eng Technol Res, vol. 3, no. 10, p. 5, 2014.

[40] H. Hartung and L. Pluschke, "The Benefits and Risks of Solar-Powered Irrigation-A Global Overview," Food and Agriculture Organization of the United: Rome, Italy, 2018.

[41] GIZ, Solar Powered Irrigation Systems (SPIS) : Technology, Economy, Impacts. 2020.

[42] S. Agrawal and A. Jain, "Sustainable deployment of solar irrigation pumps: Key determinants and strategies," Wiley Interdisciplinary Reviews: Energy and Environment, vol. 8, no. 2, p. e325, 2019.

[43] M. Aliyu, G. Hassan, S. A. Said, M. U. Siddiqui, A. T. Alawami, and I. M. Elamin, "A review of solarpowered water pumping systems," Renewable and Sustainable Energy Reviews, vol. 87, pp. 61-76, 2018.

[44] M. Niajalili, P. Mayeli, M. Naghashzadegan, and A. H. Poshtiri, "Techno-economic feasibility of offgrid solar irrigation for a rice paddy in Guilan province in Iran: A case study," Solar Energy, vol. 150, pp. 546-557, 2017.

[45] S. AGRAWAL and A. JAIN, "Financing solar for irrigation in India," Council on Energy, Environment and Water (CEEW), 2018.

[46] S. A. Moeeni and M. Alam, "Solar Photovoltaic Water Pumping System for Pressurised Irrigation Solar Photovoltaic Water Pumping System for Pressurised Irrigation."

[47] D. V Ravikumar, R. K. Sudesh, J. C. John, K. D. Kumar, and P. Vinupal, "Solar power based water pumping system with automatic irrigation using wireless technology," International journal of advanced research in electrical, electronics and instrumentation engineering, vol. 8, no. 3, p. 880-886, 2019.

[48] A. Brahmi, A. Abounada, G. Chbirik, and A. El Amrani, "Design and optimal choice of a $1.5 \mathrm{~kW}$ photovoltaic pumping system for irrigation purposes," in AIP Conference Proceedings, 2018, vol. 2056, no. 1, p. 20004.

[49] M. El-Shimy, M. Nour Eldeen, and T. Abdo Mohamed, "Irrigation water pumping (IWP) systemscomparison between photovoltaics and conventional energy sources," Inženjerstvo okoliša, vol. 3, no. 2, pp. 7-20, 2016.

[50] S. Lal, P. Kumar, and R. Rajora, "Performance analysis of photovoltaic based submersible water pump," International Journal of engineering and technology (IJET), vol. 5, pp. 552-560, 2013.

[51] M. Newkirk, "«What are monocrystalline, polycrystalline and thin film solar panels?»." .

[52] A. Alshamani, "Design and modelling of a large-scale solar water pumping system for irrigation in Saudi Arabia." Memorial University of Newfoundland, 2018.

[53] G. Olsson, Clean Water Using Solar and Wind: Opportunities to reach outside the power grid. IWA Publishing, 2018.

[54] R. Gouws and T. Lukhwareni, "Factors influencing the performance and efficiency of solar water pumping systems: A review," 2012.

[55] W. Hassan and F. Kamran, "A hybrid PV/utility powered irrigation water pumping system for rural agricultural areas," Cogent Engineering, vol. 5, no. 1, p. 1466383, 2018.

[56] R. Saravanan, G. Karthikeyan, R. Sethumadhavan, S. Renganarayanan, and A. N. Rao, "Performance evaluation of solar photovoltaic water pumping system," International Journal of Current Microbiology and Applied Sciences, vol. 7, no. 12, p. 2627-2632., 2018.

[57] C. Beaton et al., Mapping Policy for Solar Irrigation Across the Water-Energy-Food (WEF) Nexus in India. International Institute for Sustainable Development, 2019.

[58] S. Verma, J. Katiyar, A. Mandavi, V. Pathak, A. Alam, and M. Lal, “A survey on automatic irrigation system using solar panel," International Journal of Advanced Research in Electrical, Electronics and Instrumentation Engineering, vol. 6, no. 5, 2017.

[59] USDA, Design of Small Photovoltaic (PV) Solar-Powered Water Pump Systems. 2017.

[60] GWE, Technology Data Sheet: Solar Water Pumping. 2014.

[61] R. J. Chilundo, U. S. Mahanjane, and D. Neves, "Design and performance of photovoltaic water pumping systems: comprehensive review towards a renewable strategy for Mozambique," Journal of Power and Energy Engineering, vol. 6, no. 7, pp. 32-63, 2018.

[62] IGEN-RE and GIZ, "Solar water pumping for irrigation: Opportinuties in Bihar, India," 2013.

[63] GIZ, Photovoltaics for productive use applicationsa catalogue of dc-appliances. 2016.

[64] A. Mihailidis, K. Panagiotidis, and K. Agouridas, "Analysis of solar panel support structures," in 3rd ANSA \& $\mu$ ETA International Coference, 2009. 
[65] XMULTIPLE, "Solar connectors, Cables, Branch Plugs, Junction Boxes, Inveters and More,” 2020.

[66] T. Stoffel et al., "Concentrating Solar Power: Best practices handbook for the collection and use of solar resource data (CSP)," National Renewable Energy Lab.(NREL), Golden, CO (United States), 2010 .

[67] FondriestEnvironmental, "Solar Radiation and Photosynethically Active Radiation." Fundamentals of Environmental Measurements," 2014. .

[68] A. A. Elbaset and S. I. H. Ata, "Optimum Photovoltaic Solar Cells Area Estimation for Feeding MicroGrid Loads."

[69] WorldBank, Solar resource and photovoltaic potential of Indonesia. 2017.

[70] L. Wald, "Basics in solar radiation at Earth surface," 2018.

[71] G. M. Masters, Renewable and efficient electric power systems. John Wiley \& Sons, 2013.

[72] Z. Er and E. Balci, "Dual axis solar angle tracking system without any sensor," Journal of Energy Systems, vol. 2, no. 3, pp. 127-136, 2018.

[73] E. Mohammed, "The optimum tilt angle and orientation for Solar panels," Journal Port Science Research, vol. 2, no. 2, pp. 259-263, 2019.

[74] M. Mohammed and H. Z. Alibaba, "The effect of photovoltaic (PV) panel tilt angle for best energy generation in hot climat."

[75] J. Simon and G. Mosey, Feasibility Study of Economics and Performance of Solar Photovoltaics at the VAG Mine Site in Eden and Lowell, Vermont : A Study Prepared in Partnership with the Environmental Protection Agency for the RE-Powering America's Land Initiative : Siting Renewa. 2013.

[76] S. C. Bhatia, Solar divices. Advanced renewable energy systems. 2014.

[77] V. J. Fesharaki, M. Dehghani, J. J. Fesharaki, and H. Tavasoli, "The effect of temperature on photovoltaic cell efficiency," in Proceedings of the 1stInternational Conference on Emerging Trends in Energy Conservation-ETEC, Tehran, Iran, 2011, pp. 20-21.

[78] GSES, A practical guide to PV efficiency. 2016.

[79] P. E. Chris Callahan and U. V. M. Waterman, "Solar Water Pumping Basics." Project of Agricultural Engineering, The University of Tennesse, 2013.

[80] L. C. Kelley, E. Gilbertson, A. Sheikh, S. D. Eppinger, and S. Dubowsky, "On the feasibility of solarpowered irrigation," Renewable and Sustainable Energy Reviews, vol. 14, no. 9, pp. 2669-2682, 2010.

[81] R. Munarto and A. Faishal, "Feasibility study of photovoltaic water pump for rice paddy irrigation," in MATEC Web of Conferences, 2018, vol. 218, p. 2011.

[82] J. Schnetzer and L. Pluschke, "Solar-powered irrigation systems: a clean-energy, low-emission option for irrigation development and modernization.," Solar-powered irrigation systems: a clean-energy, low-emission option for irrigation development and modernization., 2017.

[83] M. Cloutier and P. Rowley, "The feasibility of renewable energy sources for pumping clean water in sub-Saharan Africa: A case study for Central Nigeria," Renewable Energy, vol. 36, no. 8, pp. 22202226, 2011.

[84] A. Hadidi and M. Yaichi, "Solar system design for water pumping," in E3S Web of Conferences 37, $06001,2018$.

[85] ICID, No TitleSolar Powered Irrigation Systems in India : Lessons for Africa Through a FAO Study Tour. 2019.

[86] A. Rahman and B. P. Bhatt, "Scope of solar energy groundwater pumping in eastern India," The Ecoscan, vol. 8, no. 1\&2, pp. 121-125, 2014.

[87] J. R. Anoop and N. Reema, "Evolution of solar powered water pumping system," International Journal of Innovative Research in Science, Engineering and Technology, vol. 6, no. 2, 2017.

[88] M. Benghanem, K. O. Daffallah, A. A. Joraid, S. N. Alamri, and A. Jaber, "Performances of solar water pumping system using helical pump for a deep well: A case study for Madinah, Saudi Arabia," Energy Conversion and Management, vol. 65, pp. 50-56, 2013.

[89] S. Karahocagil, N. Mutlu, U. Atay, Y. Dagtekin, and M. Sirer, "Pilot solar irrigation applications in Southeastern Anatolia region : A multi-parameter analysis based on statistical data."

[90] K. R. Curtis, "Economic feasibility of solar photovoltaic irrigation system use in great basin forage production," 2010.

[91] S. S. Chandel, M. N. Naik, and R. Chandel, "Review of performance studies of direct coupled photovoltaic water pumping systems and case study," Renewable and Sustainable Energy Reviews, vol. 76, pp. 163-175, 2017.

[92] UNICEF, Scaling up solar powred water supply systems : A review of experiences. 2016.

[93] X. Gao et al., "Feasibility evaluation of solar photovoltaic pumping irrigation system based on analysis of dynamic variation of groundwater table," Applied energy, vol. 105, pp. 182-193, 2013. 
[94] D. M. Das, R. Toppo, and C. SWCE, "Feasibility Study of 0.1 HP Nano Solar Pump with Gravity based Drip Irrigation System for Vegetable Cultivation," Int. J. Curr. Microbiol. App. Sci, vol. 7, no. 6, pp. 3825-3833, 2018.

[95] A. Batman, F. G. Bagriyanik, Z. E. Aygen, Ö. Gül, and M. Bagriyanik, "A feasibility study of gridconnected photovoltaic systems in Istanbul, Turkey," Renewable and Sustainable Energy Reviews, vol. 16, no. 8, pp. 5678-5686, 2012.

[96] M. N. Kaya and F. Köse, "Renewable Energy Powered Rural Irrigation : Feasibility Comparison of Solar And Wind Based Water Pumping Systems in Turkey," in ANNUAL INTERNATIONAL CONFERENCES Volume 21, p. 76.

[97] M. A. Hossain, M. S. Hassan, M. A. Mottalib, and M. Hossain, "Feasibility of solar pump for sustainable irrigation in Bangladesh," International Journal of Energy and Environmental Engineering, vol. 6, no. 2, pp. 147-155, 2015.

[98] D. Feldman, G. Barbose, R. Margolis, R. Wiser, N. Darghouth, and A. Goodrich, "Photovoltaic (PV) pricing trends: historical, recent, and near-term projections," Lawrence Berkeley National Lab.(LBNL), Berkeley, CA (United States), 2012.

[99] M. Al-Saidi and N. Lahham, "Solar energy farming as a development innovation for vulnerable water basins," Development in Practice, vol. 29, no. 5, pp. 619-634, 2019.

[100] V. Garg, "India: Vast potential in solar-powered irrigation," Institute for Energy Economics and Financial Analysis, Cleveland, Ohio, 2018.

[101] M. Otoo, N. Lefore, P. Schmitter, J. Barron, and G. Gebregziabher, Business model scenarios and suitability: smallholder solar pump-based irrigation in Ethiopia. Agricultural Water ManagementMaking a Business Case for Smallholders, vol. 172. International Water Management Institute (IWMI), 2018.

[102] H. Biswas and F. Hossain, "Solar Pump : A Possible Solution of Irrigation and Electric Power Crisis of Bangladesh,” International Journal of Computer Applications, vol. 62, no. 16, 2013.

[103] KPMG, Feasibility analysis for solar agricultural water pumps in India. 2014.

[104] S. Mekhilef, S. Z. Faramarzi, R. Saidur, and Z. Salam, "The application of solar technologies for sustainable development of agricultural sector," Renewable and sustainable energy reviews, vol. 18, pp. 583-594, 2013.

[105] A. Nikzad, M. Chahartaghi, and M. H. Ahmadi, "Technical, economic, and environmental modeling of solar water pump for irrigation of rice in Mazandaran province in Iran: A case study," Journal of Cleaner Production, vol. 239, p. 118007, 2019.

[106] A. Copeland, "Solar Water Pumps in Zambia : Irrigating the Fields of Shamiyoyo," 2018.

[107] P. D. Narale, N. S. Rathore, and M. M. Lad, "Techno economic assessment of solar photovoltaic water pumping system.," International Journal of Agricultural Engineering, vol. 7, no. 1, pp. 1-6, 2014.

[108] GET.invest, Senegal : Renewable Energy in Agricultural Value Chains : Model Business Case : Solar Photovoltaic Water Pumping for Small-Scale Irrigation Scheme with Low Water Demand. 2019.

[109] M. Hammad and M. S. Y. Ebaid, "Comparative economic viability and environmental impact of PV, diesel and grid systems for large underground water pumping application (55 wells) in Jordan," Renewables: Wind, Water, and Solar, vol. 2, no. 1, p. 12, 2015.

[110] B. Ali, "Comparative assessment of the feasibility for solar irrigation pumps in Sudan," Renewable and Sustainable Energy Reviews, vol. 81, pp. 413-420, 2018.

[111] A. Bakhsh, J. N. Chauhdary, A. Ali, M. Rizwan, and M. Hussain, "Tube well run on solar energy and its use in agriculture," 2016.

[112] LORENTZ, Solar Water Pumping for Center Pivot Irrigation North Africa. 2014.

[113] C. Lorenzo, R. H. Almeida, M. Martínez-Núñez, L. Narvarte, and L. M. Carrasco, "Economic assessment of large power photovoltaic irrigation systems in the ECOWAS region," Energy, vol. 155, pp. 992-1003, 2018.

[114] J. A. C. Bolanos, W. Ortiz, and R. Bhandari, "Techno-economic feasibility study of solar and wind based irrigation systems in Northern Colombia," 2015.

[115] M. A. Hossain, M. S. Hassan, M. A. Mottalib, and S. Ahmmed, "Technical and economic feasibility of solar pump irrigations for eco-friendly environment," Procedia Engineering, vol. 105, pp. 670-678, 2015.

[116] A. M. García, J. Gallagher, A. McNabola, E. C. Poyato, P. M. Barrios, and J. A. R. Díaz, “Comparing the environmental and economic impacts of on-or off-grid solar photovoltaics with traditional energy sources for rural irrigation systems," Renewable Energy, vol. 140, pp. 895-904, 2019.

[117] A. M. García, I. F. García, E. C. Poyato, P. M. Barrios, and J. A. R. Díaz, "Coupling irrigation scheduling with solar energy production in a smart irrigation management system," Journal of Cleaner 
Production, vol. 175, pp. 670-682, 2018.

[118] M. T. C. Cobo, E. C. Poyato, M. P. M. Barrios, and J. A. R. Díaz, "Assessing the potential of solar energy in pressurized irrigation networks. The case of Bembézar MI irrigation district (Spain)," Spanish journal of agricultural research, no. 3, pp. 838-849, 2014.

[119] E. B. No, J. Paulsen, T. Reynolds, M. K. Gugerty, and S. Bolton, “Alternative Energy Pumps to Irrigate Smallholder Farmers' Land: What is the State of the Art?"

[120] E-MFP, "Solar water pumps," 2015.

[121] G. Todde et al., "Energy and environmental performances of hybrid photovoltaic irrigation systems in Mediterranean intensive and super-intensive olive orchards," Science of the Total Environment, vol. 651, pp. 2514-2523, 2019.

[122] A. Chel and G. Kaushik, "Renewable energy for sustainable agriculture," Agronomy for Sustainable Development, vol. 31, no. 1, pp. 91-118, 2011.

[123] H. Shim, Case Study: Solar-PoweredIrrigation Pumps in India-Capital Subsidy Policies and the Water-Energy Efficiency Nexus. 2017.

[124] T. D. Dekker, "Solarizing Indian agriculture by deploying solar irrigation pumps." 2015.

[125] M. A. Shoeb and G. M. Shafiullah, "Renewable energy integrated islanded microgrid for sustainable irrigation-A Bangladesh perspective,” Energies, vol. 11, no. 5, p. 1283, 2018.

[126] CFI, Bangladesh : Power system efficiency improvement project - Additional financing - off gri solar PV: Solar irrigation. 2017.

[127] IRENA, "Solar pumping for irrigation: Improving livelihoods and sustainability," The International Renewable Energy Agency, 2016.

[128] J. Yang, A. Olsson, J. Yan, and B. Chen, "A hybrid life-cycle assessment of CO2 emissions of a PV water pumping system in China," Energy Procedia, vol. 61, pp. 2871-2875, 2014.

[129] A. M. Armanuos, A. Negm, and A. H. M. H. El Tahan, "Life cycle assessment of diesel fuel and solar pumps in operation stage for rice cultivation in Tanta, Nile Delta, Egypt," Procedia Technology, vol. 22, pp. 478-485, 2016. 